\title{
Tectonic segmentation across Patagonia controlled by the subduction of oceanic fracture zones
}

\author{
Darío Leandro Orts ${ }^{\mathrm{a}, \mathrm{b}, *}$, Orlando Álvarez ${ }^{\mathrm{c}}$, Claudia Zaffarana ${ }^{\mathrm{a}, \mathrm{b}}$, Mario Gimenez ${ }^{\mathrm{c}}$, \\ Francisco Ruiz $^{\mathrm{c}}$, Andrés Folguera ${ }^{\mathrm{d}}$ \\ ${ }^{\text {a } U n i v e r s i d a d ~ N a c i o n a l ~ d e ~ R i ́ o ~ N e g r o, ~ I n s t i t u t o ~ d e ~ I n v e s t i g a c i o ́ n ~ e n ~ P a l e o b i o l o g i ́ a ~ y ~ G e o l o g i ́ a, ~ R i ́ o ~ N e g r o, ~ A r g e n t i n a ~}$ \\ ${ }^{\mathrm{b}}$ IIPG, UNRN, Consejo Nacional de Investigaciones científicas y Tecnológicas (CONICET), Av. Roca 1242, (R8332EXZ), General Roca, Río Negro, Argentina \\ ${ }^{\mathrm{c}}$ Instituto Geofísico y Sismológico Ing. Volponi, Universidad Nacional de San Juan-CONICET, San Juan, Argentina \\ ${ }^{\mathrm{d}}$ Instituto de Estudios Andinos "Don Pablo Groeber", Universidad de Buenos Aires-CONICET, Ciudad Autónoma de Buenos Aires, Argentina
}

\section{A R T I C L E I N F O}

\section{Keywords:}

Fracture zones

Upper plate deformation

Southern South America

Seismogenic behavior

Coupling zone

Long-term deformation

\begin{abstract}
A B S T R A C T
A set of fracture zones left by transform faults segmenting the active Chile Ridge that separates the Nazca and Antarctica Plates has been subducting beneath western Patagonia in the last 18 Myr. The subduction direction of these fractures zones has remained almost unaltered during this time lapse since these intersected the Chilean trench. In this context, the analyzed Patagonian sector is associated with the subduction of a highly buoyant oceanic floor due to its relatively young age that contrasts with the ocean floor bathymetry to the north where oceanic crust gets progressively older up to the Eocene and consequently isostatically subsides. Short-term elastic deformational patterns associated with the earthquake cycle have been linked to this segmentation imposed by subducting fracture zones in previous works. Similarly, this work explores the relationship between long-term topography, seismicity, gravity, and magnetic anomalies as a proxy for upper crustal structure, deformation, exhumation, and consequently surface geology segmented nature associated with this pattern of oceanic fracture zones. Through these analyses, we have identified a series of ENE structural trends or lineaments across the continental crust that could be directly related to the segmented mechanical behavior of the plate interface and enhanced by particular climatic and tectonic history of the Patagonian region. These evidences could contribute to the understanding of how fracture zones can control, to a certain extent, the segmented nature of the upper plate in a subduction setting.
\end{abstract}

\section{Introduction}

The mechanisms that control seismogenic segmentation, plate coupling and permanent deformation in a subduction zone are far from being completely understood. The subduction of bathymetric anomalies of the oceanic crust and the uneven accumulation of sediments along the trench are presently considered short- and long-term conditionings of permanent deformation and seismogenic segmentation (Vogt et al., 1976; Jordan et al., 1983; Gutscher et al., 1999, 2000; Das and Watts, 2009; Rosenbaum and Mo, 2011; Heuret et al., 2012; Müller and Landgrebe, 2012). In particular, sediments accumulated in the Chilean trench and then transported down into the subduction channel, and the highly serpentinized oceanic crust affect together plate coupling determining the duration of interseismic cycles and the length of rupture zones through the subduction margin (Bray and Karig, 1985; Hackney et al., 2006; Heuret et al., 2012; Contreras-Reyes et al., 2013; Völker et al., 2013; Spikings and Simpson, 2014; Moreno et al., 2014; Bassett and Watts, 2015a, b). Consequently, the forearc has a variable architecture as a function of interseismic or coseismic capability to absorb brittle and ductile deformation (Contreras-Reyes and Carrizo, 2011; Moreno et al., 2011, 2012; Melnick, 2016). Additionally, sediment and ocean crust basal accretion and crustal erosion affect the forearc configuration at short- and long-term temporal scales (Melnick et al., 2009; Encinas et al., 2012, 2016; Maksymowicz et al., 2012; Maksymowicz, 2015; Noda, 2016). The capability to retain and outflow fluids in the subduction system depends, to a certain extent, on faulting generated at the outer rise and the development of fault networks related to fracture zones (FZ) previously to subduction (Contreras-Reyes et al., 2008; Dzierma et al., 2012a; Moreno et al., 2014; Völker and Stipp, 2015). Thus, frictional forces acting in the plate interface (Lay

\footnotetext{
* Corresponding author at: Universidad Nacional de Río Negro, Instituto de Investigación en Paleobiología y Geología, Río Negro, Argentina.

E-mail address: dorts@unrn.edu.ar (D.L. Orts).
} 
et al., 2012; Cubas et al., 2013) may define locking or localized creeping zones related to the subducting slab morphology and physical properties.

In this work, we analyze a hypothesis in which the stepped and shallower relief of the ocean floor surrounding the Chile Ridge, delimited by fracture zones (FZ), has a permanent effect in surficial and deep crustal deformation, segmenting the upper plate in the North Patagonian subduction setting (Fig. 1). Additionally, this work extends the analysis to the retroarc foreland zone extending previous proposals that analyzed the deformational patterns restricted to the forearc and arc zones (Hackney et al., 2006; Contreras-Reyes et al., 2008; Dzierma et al., 2012a; Bassett and Watts, 2015a; 2015b; Maksymowicz, 2015; Martinod et al., 2016).

The oceanic FZs are defined as the trace left by the transform faults that offset segments of an active mid-ocean ridge. The FZs involve an age offset of the ocean floor and consequently a bathymetric step as a product of isostatic balance (Fig. 1). Thus, this lateral contrast in ocean floor ages generates prominent ocean floor morphology breaks reaching up to $500 \mathrm{~m}$ of differential elevation such as in the Chile Ridge system (Fig. 1).

Precise paleogeographic reconstructions derived from ocean floor magnetic anomalies (Cande and Leslie, 1986; Müller et al., 2008; Eagles et al., 2009; Seton et al., 2012; Eagles and Scott, 2014; Wright et al., 2016; among others) show that this set of oceanic fracture zones has impacted against the ocean trench and subducted almost invariantly since $\sim 18 \mathrm{Myr}$ ago (Figs. 1 and 2), as a result of a relatively stable stage
Euler vector between Nazca and South American Plates $\left(\sim\right.$ N78 ${ }^{\circ}$ E) (e.g. Somoza, 1998; Somoza and Ghidella, 2005; Wright et al., 2016). This configuration would have resulted after a major plate reorganization $\sim 25$ Myr ago following the rupture of Farallon Plate into Nazca and Cocos Plates. These reconstructions indicate that those fracture zones with similar orientation with the convergence vector (the only exception is the oblique-to-the-margin Mocha FZ) would have subducted in the same place along the trench since $\sim 18 \mathrm{Myr}$ ago onwards (Fig. 2).

Additionally, some of these fracture zones, such as the Valdivia FZ, develop up to $50 \mathrm{~km}$ wide fault systems that favor fluid circulation and the deep penetration of hydrothermal alteration and serpentinization of the oceanic crust and upper mantle (Dzierma et al., 2012a; Moreno et al., 2014). This anomalous fluid content and therefore higher pore-fluid pressure affect the degree of coupling at the plate interface (Moreno et al., 2014). Therefore, the zones of the Andean margin where the fracture zones are subducted show less degree of coupling in comparison to the oceanic crust segments delimited by them (Métois et al., 2016), having those segments longer seismic cycles where the interseismic elastic deformation is preferentially accumulated. In this sense, many studies have observed the correlation between these segments delimited by FZs and the occurrence of major earthquakes characterized by broader rupture zones, with longer interseismic cycles (Carena, 2011; Müller and Landgrebe, 2012; Moreno et al., 2011), and with gravity anomalies that illuminate seismic segmentation of the forearc zone (Song, 2003; Wells et al., 2003; Álvarez et al., 2014).

Therefore, this work constitutes an analysis of different types of data

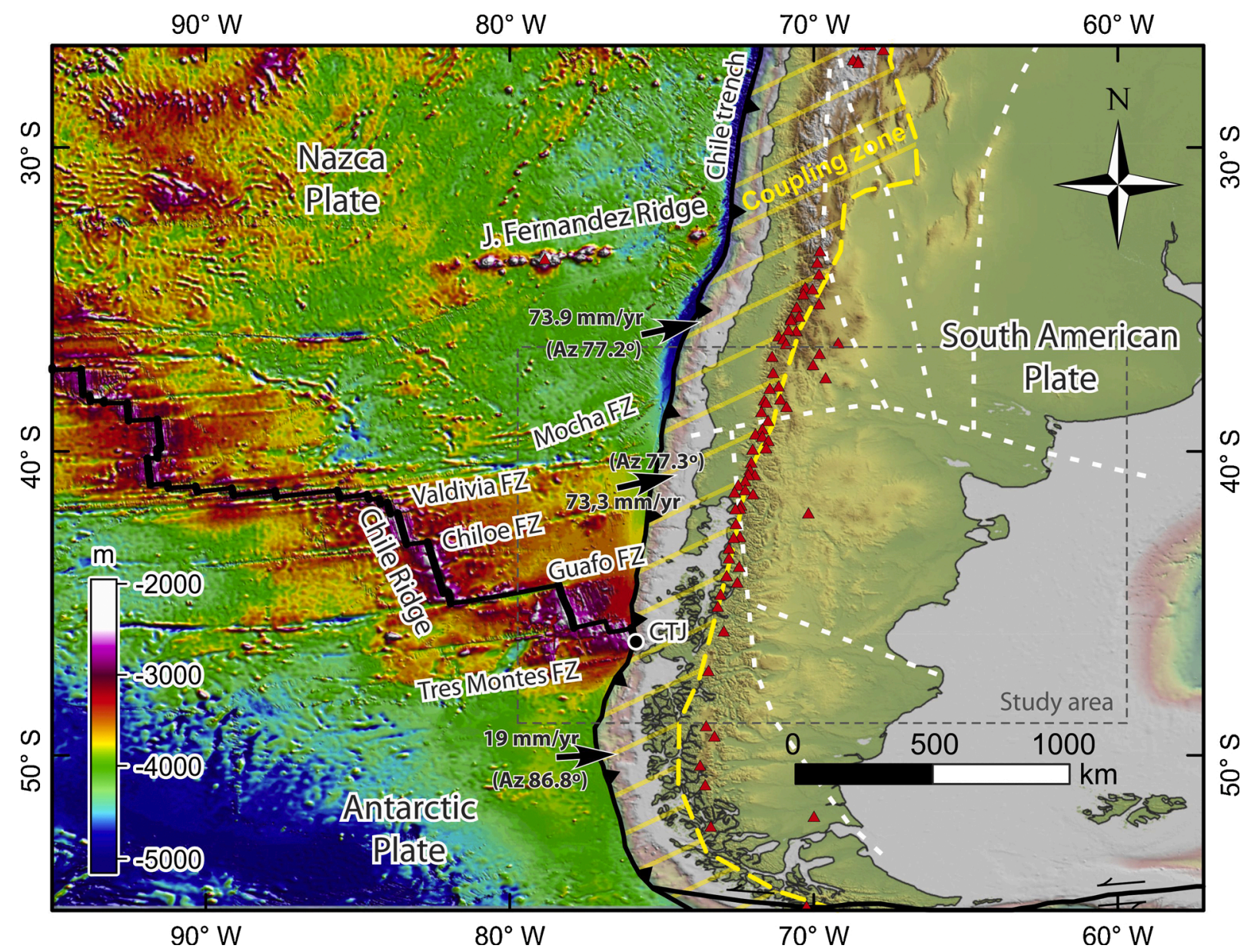

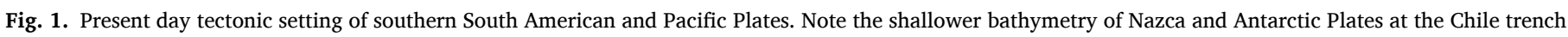

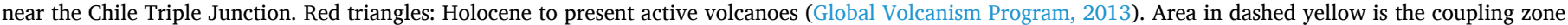

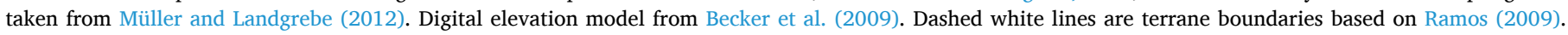

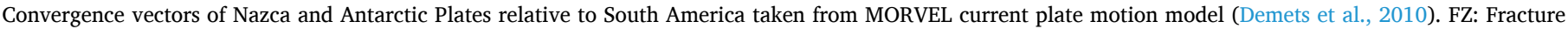
zone; CTJ: Chile Triple Junction. 


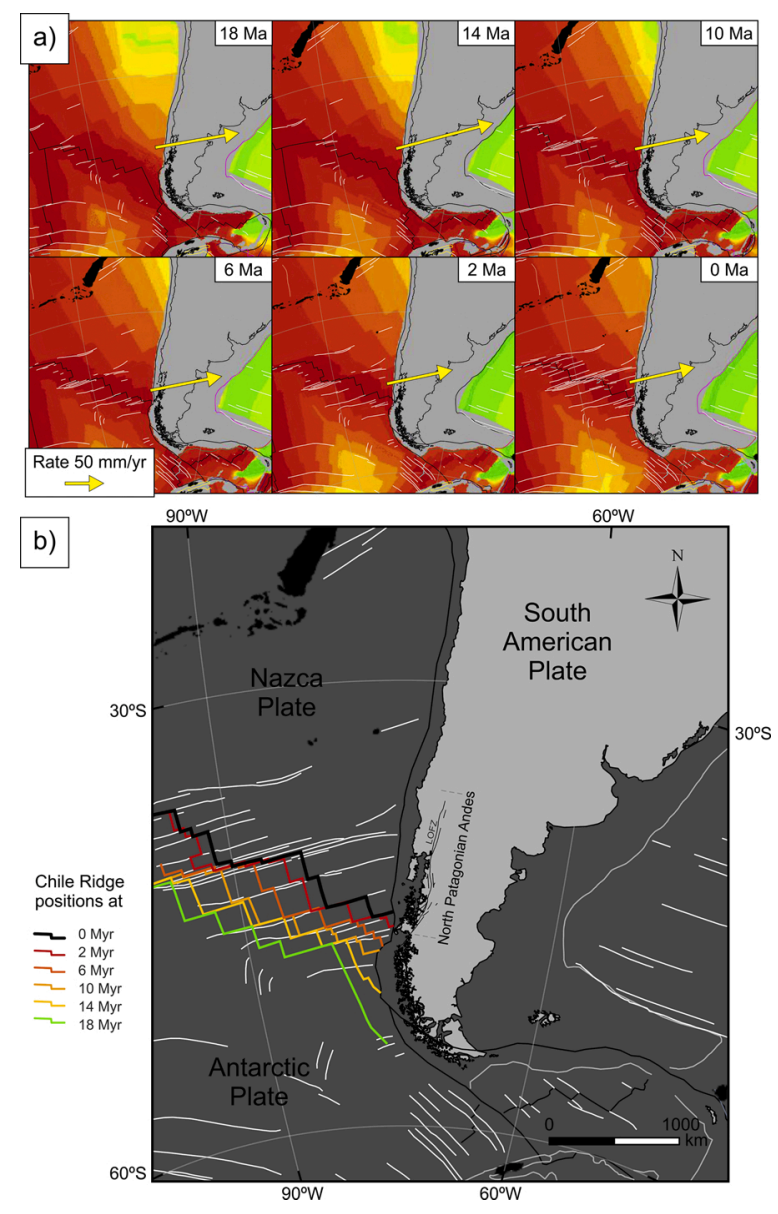

Fig. 2. South American Plate interactions with the Pacific (Nazca and Antarctic) oceanic plates in the last $18 \mathrm{Myr}$. a) Reconstructions highlighting the evolution of the Chile Ridge and Nazca-South American Plates convergence (taken from Müller et al., 2016; Wright et al., 2016; Eagles et al., 2014). The yellow arrows show convergence rates between Nazca and South American Plates (taken from Wright et al., 2016). b) Chile Ridge positions since $18 \mathrm{Myr}$ depicted in a fixed South American Plate reference frame. Light grey lines are the present tectonic fabric of the ocean floor (fracture zones) taken from Matthews et al. (2011). LOFZ: Liquiñe Ofqui Fault Zone (Hervé, 1994; Cembrano and Lara, 2009).

sets that synthesize: i) Regional geology maps; ii) topographic and bathymetric digital elevation models (Jarvis et al., 2008; Becker et al., 2009); iii) seismicity catalogs (IRIS Data Management Center); iv) global gravity models, as EGM2008 (Pavlis et al., 2012) and GOCE (GO_CONS_GCF_2_TIM_R5 from Bruinsma et al., 2013); v) global magnetic intensity map EMAG2 (Maus, 2009), with the aim of establishing their link to segmentation of the ocean floor imposed by FZs. Finally, the purpose of this analysis is to demonstrate the correlation that exists between segments delimited by FZs and the long-term deformational trends through the North Patagonian crust with applicability to other subduction settings in the world.

\section{Long-term deformations inferred from seismicity patterns}

Even though different controls have been proposed for interplate seismicity and slip patterns, the bathymetric irregularities related to slab relief along the intraplate contact and the variable volume of subducting sediments seem to regulate lateral propagation of megathrust rupture zones (e.g. Sparkes et al., 2010; Wang and Bilek, 2014; Contreras-Reyes and Carrizo, 2011; Hauret et al., 2012). In particular, the subduction system seismic behavior in southern South America shows along-strike variations observable in the historical seismicity (Fig. 3) and in megathrust segmentation (e.g. Loveless et al., 2009, 2010; Melnick et al., 2009). The study region, located in North Patagonia, provides good preservation of long-lived and ongoing Andean deformations $(<18$ Myr), relief morphology, crustal structure, and intraplate seismicity and megaearthquake slip distributions to establish direct correlations among these parameters (Fig. 3 a,b). For example, complexities in the rupture zone of megaearthquakes, like for the 1960 Valdivia $(\mathrm{Mw}=9.5)$ earthquake, could be explained by the segmented nature of the subducting oceanic Nazca Plate. The heterogeneities of the Nazca and Antarctic Plates at the Chilean trench are essentially related to age off-sets generated by the transform faults at the active Chile Ridge, which are observed as discontinuities in the linear magnetic anomalies stripes (Fig. 4).

We plotted the seismicity from 1960 to the present (Fig. 3a and b) obtained from the IRIS Data Management Center (http://ds.iris.edu /wilber3/), a catalog that combines data from existing global networks (ISC, NEIC, ESB, among others), to test the segmented nature of shallow seismicity. Fig. 3a shows the registered seismicity up to $50 \mathrm{~km}$ depth, mixing seismicity at the plate interface as well as the crustal seismicity of the lower and upper plate. Major active crustal structures across the Patagonian Andes are identified where upper crustal seismicity ( $<10 \mathrm{~km}$ depth, yellow dots) and intermediate seismicity (20-30 $\mathrm{km}$ depth, reddish dots) are nucleated (Fig. 3a). Fig. 3b shows an earthquake density plot within a $7.5 \mathrm{~km}$ radius for the aforementioned data. This type of plot allows us to devise a series of elongated clusters in the forearc, arc and retroarc with ENE orientation and circular clusters located at the interceptions between the intraplate Liquiñe-Ofqui Fault Zone (LOFZ) and the FZs projections (Fig. 3b). These are mostly seismic swarms that depict active crustal structures at depth. The northernmost cluster of events is related to the 2010 Maule $(\mathrm{Mw}=8.8)$ earthquake aftershocks and its triggered seismicity. Also, the latest major earthquake, 2016 Chiloé $(\mathrm{Mw}=7.6$ ), occurred at the southern tip of the homonymous island and immediately north of the Guafo FZ prolongation (Fig. 3).

Along-strike distribution of plate coupling derived from Global Position System (GPS) data modeling (e.g. Moreno et al., 2011; Métois et al., 2016) is a good indicator of seismic cycle behavior and related crustal deformation (Fig. 3c). From the Moreno et al. (2011) analysis of the locking degree previous to the Maule $2010(\mathrm{Mw}=8.8)$ earthquake, we can observe a segmentation that visually coincides with patches of high and low locking partially controlled by the interaction of the FZs at the plate interface. This segmented nature also coincides with the computed coseismic slips for the 1960 Valdivia $(\mathrm{Mw}=9.5)$ and 2010 Maule (Mw = 8.8) earthquakes (Moreno et al., 2009; Tong et al., 2010). The highest coseismic slip of the 1960 Valdivia $(\mathrm{Mw}=9.5)$ earthquake is found between the Chiloé and Valvidia FZs near the Chilean coast (Fig. 3d) reaching up $40 \mathrm{~m}$ of dip-slip. This zone is also contained in a high coupling domain (Fig. 3c). Two other zones of major slip concentration are located north of Guamblin and Guafo FZs with values between 20 and $30 \mathrm{~m}$ of dip-slip. These two restricted zones also coincide with two minor domains of high locking degree (Fig. 3c). A preliminary explanation to this behavior is that the stepped morphology of FZs delimits segments that concentrate interplate coupling due to their localized laterally homogeneous mechanical properties. Seismic tomographic surveys near Mocha FZ (Fig. 3e, Moreno et al., 2014) and Valdivia FZ (Fig. 3f, Dzierma et al., 2012a) show pronounced Vp/Vs anomalies suggesting that the subducting oceanic crust and the interplate shear zone are strongly hydrated (Moreno et al., 2014). So, variations in pore-fluid pressure caused by the subduction and dehydration of hydrothermally altered oceanic FZs could control the degree of interseismic locking and, therefore the slip distribution of large earthquake ruptures (Moreno et al., 2014) (Fig. 3c,d).

Even though registered earthquakes with $<\mathrm{Mw}=4$ are scarce due to the low density of the seismological network, the available data allow us to devise a general segmentation pattern reaching the retroarc area similar to the coseismic slip and locking degrees patterns derived from 

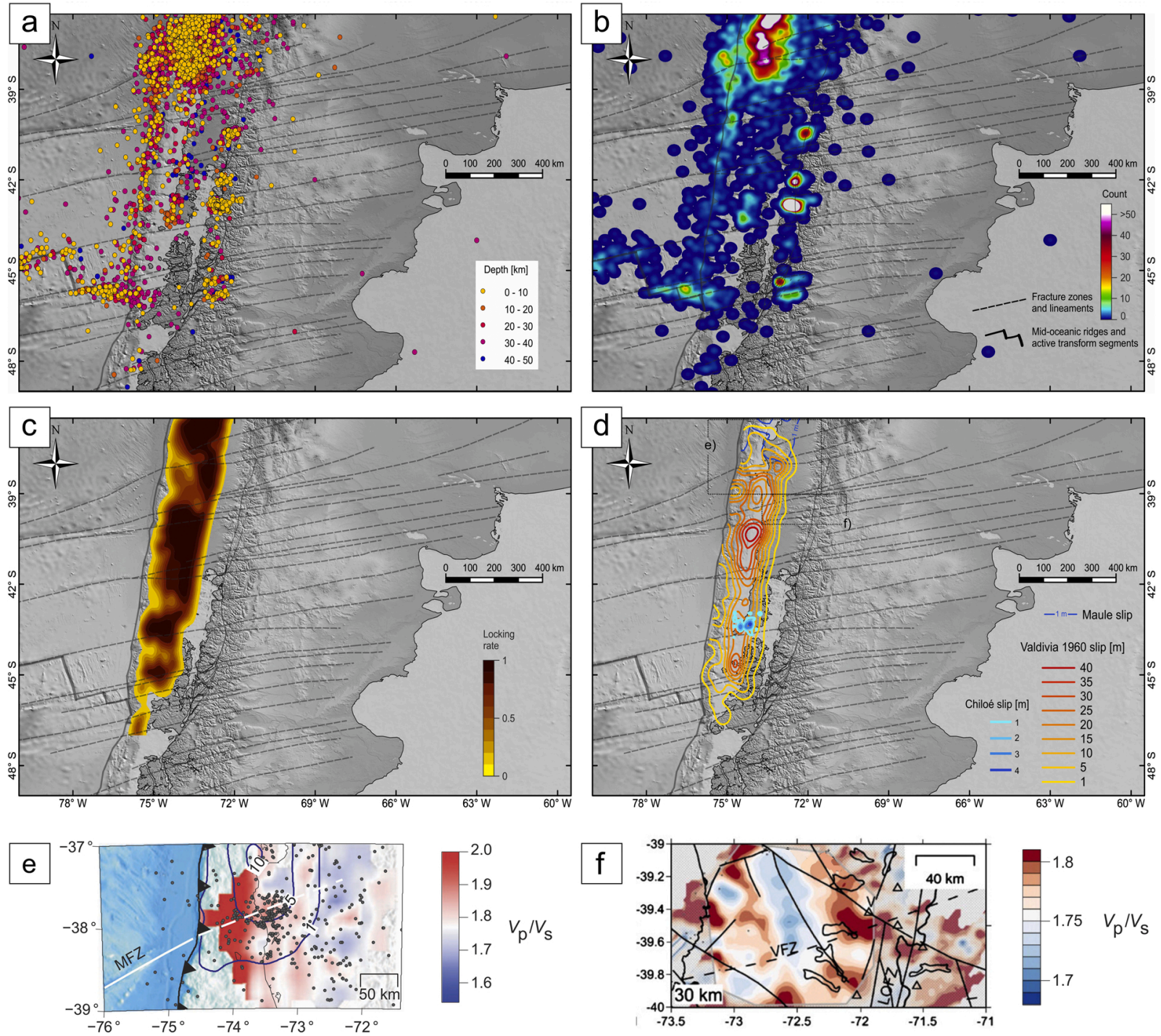

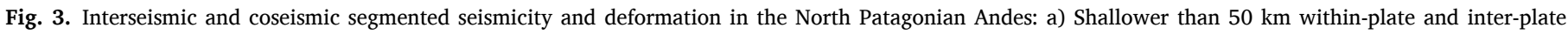

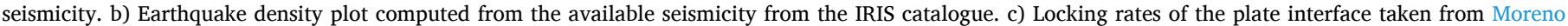

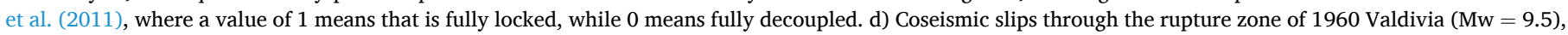

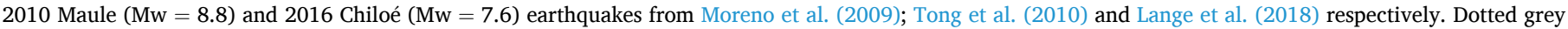

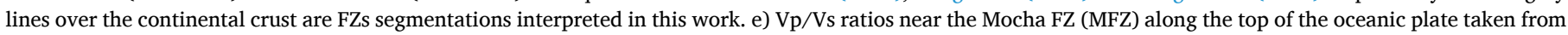

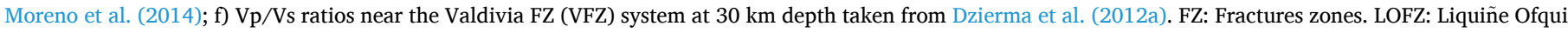
Fault Zone.

GPS velocities (Fig. 3). The width and length of the seismic activity clusters towards the retroarc area as devised in Fig. 3a,b comprise lateral variations along-strike of the North Patagonian Andes. This activity could be in response to several factors, such as interactions with the LOFZ, retroarc main decollements, or transfer zones.

\section{Surface segmentation through topographic expression and relief anomalies}

Many studies have discussed the long-wavelength topography of the Southern Andes in order to establish their lithospheric dynamic controls (e.g. Lithgow-Bertelloni and Gurnis, 1997; Flament et al., 2015). However, short-wavelength topography has also shown to represent a key element to characterize the dynamics of the subduction system linking morphotectonic features to surface and subsurface processes (Isacks, 1988; Cloetingh et al., 2005; Bassett and Watts, 2015a, b; Strecker et al., 2009; Armijo et al., 2015; Maksymowicz, 2015). In this work, we isolate short-wavelength topographic anomalies and relate them to subducted bathymetric anomalies, performing a series of topographic and relief analyses at a regional scale (Figs. 5 and 6). The concept of relief (or local relief) is based on the difference between minimum and maximum topography within a given area of limited extent. The aim of this analysis was to characterize the potential surface expression of the subducted oceanic FZs in the continental crust. Then, a regional relief model was calculated using the digital elevation model SRTM v4.1 (Jarvis et al., 2008) which is a void filled model with a spatial resolution of 3 arc $\sec (\sim 90 \mathrm{~m})$. Firstly, we applied a relief calculation through a $2.5 \mathrm{~km}$ radius moving window, obtaining the difference between the minimum and maximum elevations, and then we smoothed it with a $10 \times 10 \mathrm{~km}$ moving average window to obtain a regular grid of $0.5 \times 0.5 \mathrm{~km}$ as shown in Figs. 5 and 6. Additionally, we also performed a series of topographic and bathymetric swath profiles along the plate margin from $36^{\circ}$ to $50^{\circ} \mathrm{S}$ (Fig. 5) across the North Patagonian Andes from the Chilean coast up to the eastern foothills (Fig. 5). These profiles were performed perpendicular to the trace of the main oceanic FZs $\left(\sim \mathrm{N} 76^{\circ} \mathrm{E}\right)$. The bathymetric swath profiles were calculated using the digital elevation 


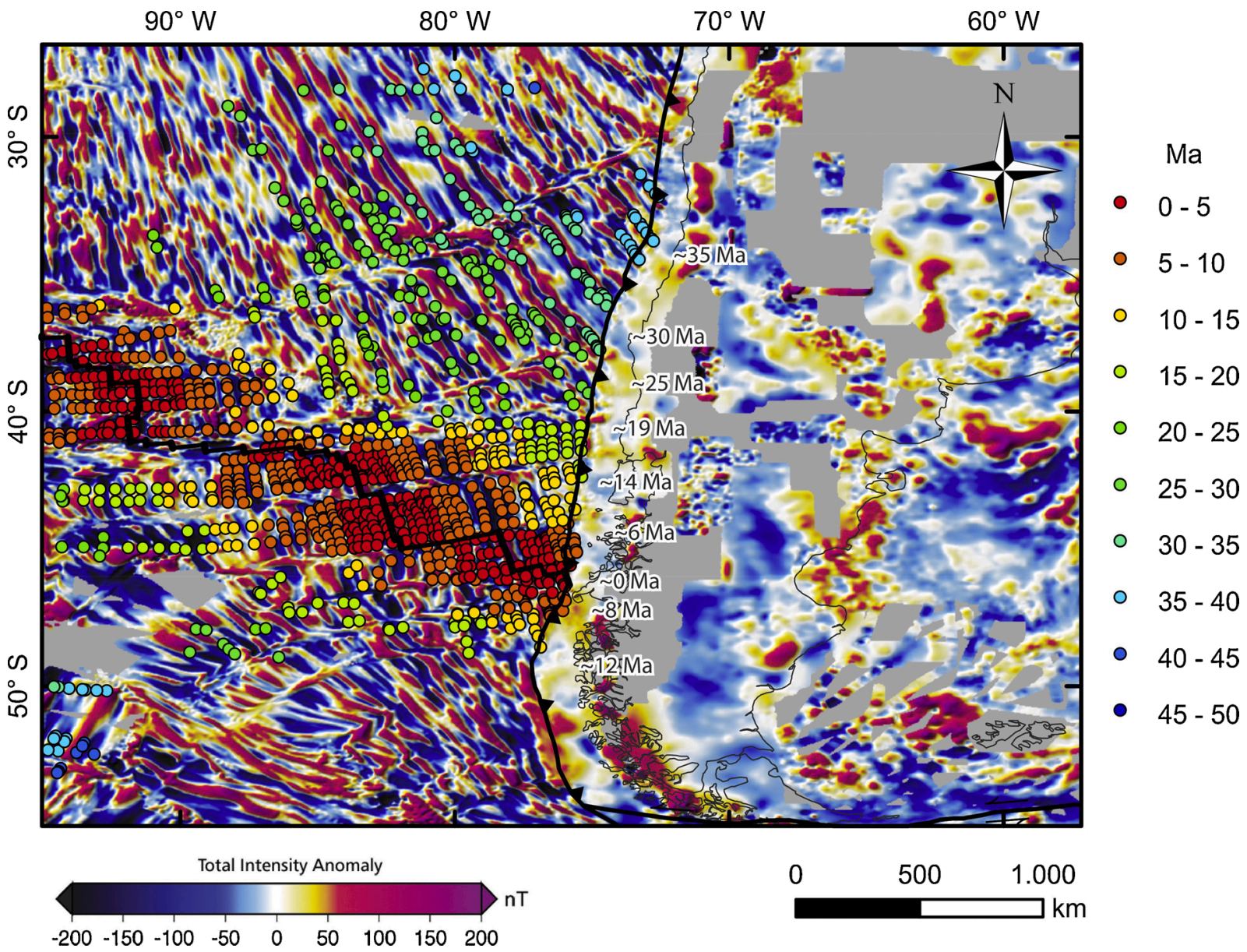

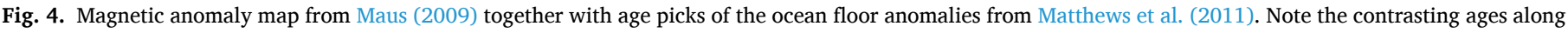

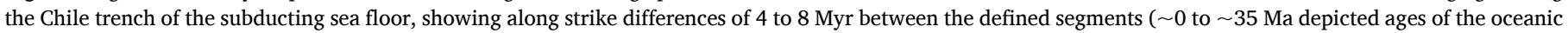
crust segments arriving at the Chile trench).

model of Becker et al. (2009) with 30 arc sec of resolution ( $1 \mathrm{~km})$. In addition to the maximum and mean topographic elevation profiles (black and blue curves in Fig. 5), we plot a profile with the maximum computed relief across the Patagonian Andes (red curve in Fig. 5) obtained from the aforementioned grid depicted in plain view. We also plotted an averaged maximum Andean topographic elevation curve (20 $\mathrm{km}$ moving average window) without considering the volcanic edifices (green curve in Fig. 5).

Therefore, from the obtained map and profiles and through a north to south analysis, we can identify that the Andean chain reaches maximum altitudes above $4000 \mathrm{~m}$ at the Principal Cordillera north of $36^{\circ} \mathrm{S}$. To the south a significant drop of $\sim 1000 \mathrm{~m}$ is observed (Fig. 5), with maximum elevations ranging between 2100 and $2300 \mathrm{~m}$ (not considering volcanic edifices). This northern topographic break coincides with the Mocha FZ location at the Chilean trench and its down-dip interaction (Fig. 5). This pattern continues to the south with a staggering decrease up to the Chile Triple Junction (CTJ). South of $36^{\circ} \mathrm{S}$ maximum elevations of $2100-2300 \mathrm{~m}$ are roughly maintained for $\sim 200 \mathrm{~km}$ up to the intersection with the Valdivia FZ, where another drop in maximum elevations is observed. Then, averaged maximum elevations keep near 1900 $\mathrm{m}$ up to the intersection with the Chiloe FZ (green curve in Fig. 5). At this site, a significant increase in relief occurs, depicted in the relief maps and in the maximum relief profile plot (red curve, Fig. 5). Here, the average maximum elevations maintain near $\sim 2000 \mathrm{~m}$ up to the Guafo FZ intersection, where the elevations drop to near $\sim 1800 \mathrm{~m}$ with another smaller variation at Guamblin FZ (green curve in Fig. 5). Then, at the site of the CTJ, we can observe a significant increase in maximum elevation and relief related to the collision of the different segments of the mid-oceanic active ridges and slab window generation. Additionally, it is worth noting variations in relief at the location of the Taitao, Tres Montes and Esmeralda FZs. These described averaged maximum Andean elevations (green curve in Fig. 5) show a negative correlation coefficient with respect to the mean ocean floor elevations (bottom blue curve in Fig. 5) of -0.76 computed north of the Triple Junction and -0.69 for the entire profile. This negative correlation can be also observed in an averaged correlation coefficient curve (purple curve in Fig. 5) through a $200 \mathrm{~km}$ wide sliding window. The averaged correlation coefficient curve shows negative values within the segments delineated by the FZs as an inverse staggered relation between topography and bathymetry. Also, this curve allows depicting an anomalous behavior of the segment between Guafo and Chiloé FZs showing low positive correlation coefficient values.

Other identifiable features are the relief anomalies at the sub-Andean zone to the east (relief values between 250 and $750 \mathrm{~m}$ corresponding to green areas in Figs. 5 and 6), where a series of slightly oblique-to-themargin ranges (NNW oriented) can be depicted. These foreland ranges abruptly gain or lose relief expression between segments delimited by FZs prolongations to the foreland area, like the ones between Guafo and Taitao FZs, and the one south of Esmeralda FZ (Figs. 5 and 6). Similar oblique-to-the-margin trends can be recognized in the Andean zone, like the ones depicted by relief anomalies ranging between 750-1000 m between Mocha, Valdivia and Chiloe FZs (yellow to orange colors in Figs. 5 and 6). These features are discernable among other even stronger NW-SE and NE-SW oriented crustal fabrics (Fig. 6).

To test the reliability of our own interpretations we applied to the computed relief grid an automatic lineament extraction process through 


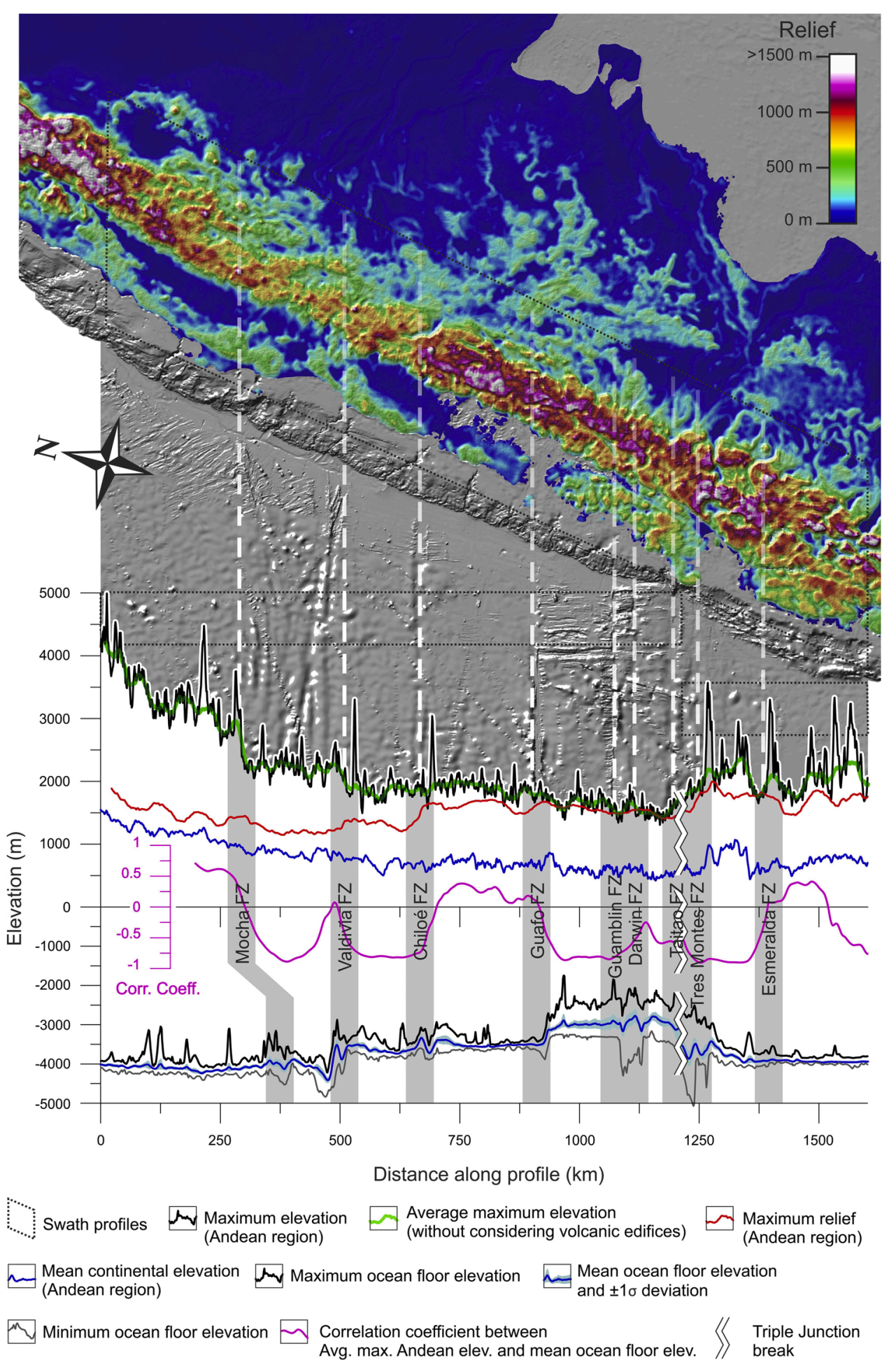

Fig. 5. Relief analysis of the Southern Andes. Above: map of the computed topographic relief within a $2.5 \mathrm{~km}$ radius. Below: Swath profiles projections perpendicular to the trace of main fracture zones across the Southern Andes and associated oceanic bathymetry. Elevation profiles from top to bottom are: maximum elevation of the Andean region (black curve), averaged maximum elevation excluding volcanic edifices (green curve), maximum relief (red curve), mean elevation (blue curve); and maximum (black curve), mean (blue curve) and minimum (grey curve) ocean floor elevations. Dash vertical white lines are approximate projection of the oceanic FZs onto the continent. The purple curve is the averaged correlation coefficient, through $200 \mathrm{~km}$ wide sliding window, between the averaged maximum Andean elevation and the mean ocean floor bathymetry along indicated swath profiles. The total computed correlation coefficient north of Triple Junction is -0.76 , and -0.69 including south of it. the pyLEFA software developed by Shevyrev $(2018,2019)$. This image analysis software includes image binarization by Canny (1986) edge detection approach and the linear Hough transform algorithm for detecting linear features. Then, the resulting linear features (length $>25$ $\mathrm{km}$ ) were added over the relief map of Fig. $6 \mathrm{~b}$. Finally, by highlighting in red color the ENE-WSW (N70-90 / N250-270 $)$ preferred orientations ( 569 solutions over a total of $n=4897$ ) a similar pattern parallel to the extrapolated FZs can be observed.

\section{Crustal segmentation identified from geoid and magnetic anomalies}

Global models of the Earth potential fields (e.g. GOCE, EGM2008, EMAG2) that combine available satellite, ship, and airborne measurements, have improved the visualization of crustal structures as never before. Therefore, the segmentation of the continental crust, particularly in Patagonia, is observed by analyzing of gravity and magnetic potential data as the geoid (Fig. 7; EGM2008) or the Earth Magnetic Anomaly Grid (EMAG2 from Maus, 2009; Fig. 8). In particular, for the geoid model, we 

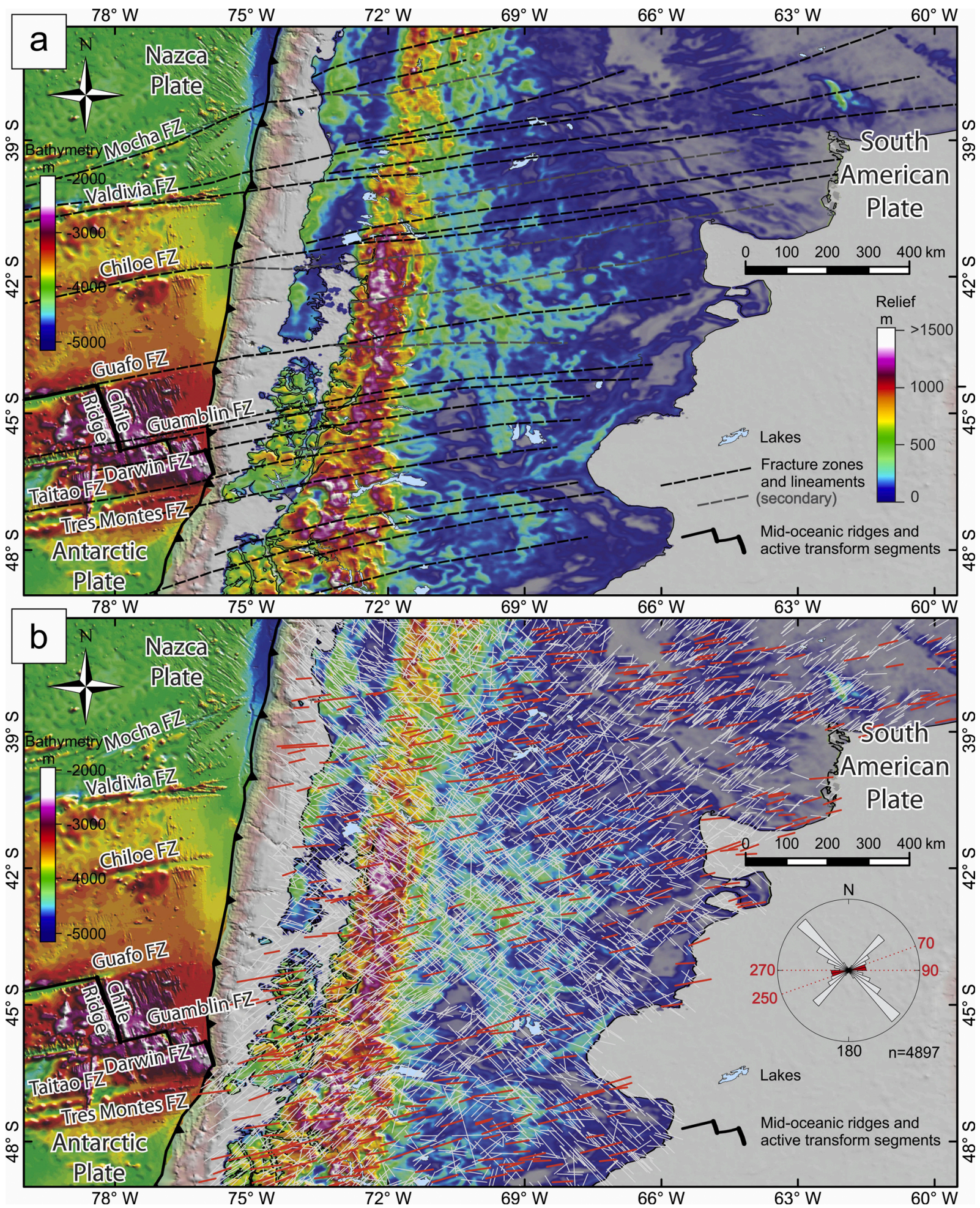

Fig. 6. a) Continental local relief (2.5 km radius) versus oceanic bathymetry and interpretation of main topographic linear breaks through the Patagonian region, coincident with extrapolation of fracture zones. b) Automatic lineament detection (length $>25 \mathrm{~km}$ ) applied over the relief grid using the pyLEFA software of image analysis developed by Shevyrev $(2018,2019)$. Highlighted in red color are the ENE-WSW lineament orientations (N70-90 and N250-270 $)$.

used the Earth Geopotencial Model EGM2008 (Pavlis et al., 2012), that represents a spherical harmonic model of the Earth's gravitational potential developed up to degree 2190 and order 2159 , composed of a worldwide surface gravity anomaly database of $5^{\prime} \times 5^{\prime}$ resolution and GRACE-derived satellite solutions. Then, we analyzed the EMAG2 global magnetic model (Maus, 2009) that has a spatial resolution of 2 arc minute and combines satellite (CHAMP), ship, and airborne measurements gridded at an altitude of $4 \mathrm{~km}$ over the WGS84 ellipsoid. Over the ocean, the model was improved by directional gridding and extrapolation based on the oceanic crustal age of Müller et al. (2008). Through the interpretation of these models we have observed and mapped ENE structures that presumably segment the continental crust at distances greater than $500 \mathrm{~km}$ within the Patagonian shelf (Figs. 7 and 8). 

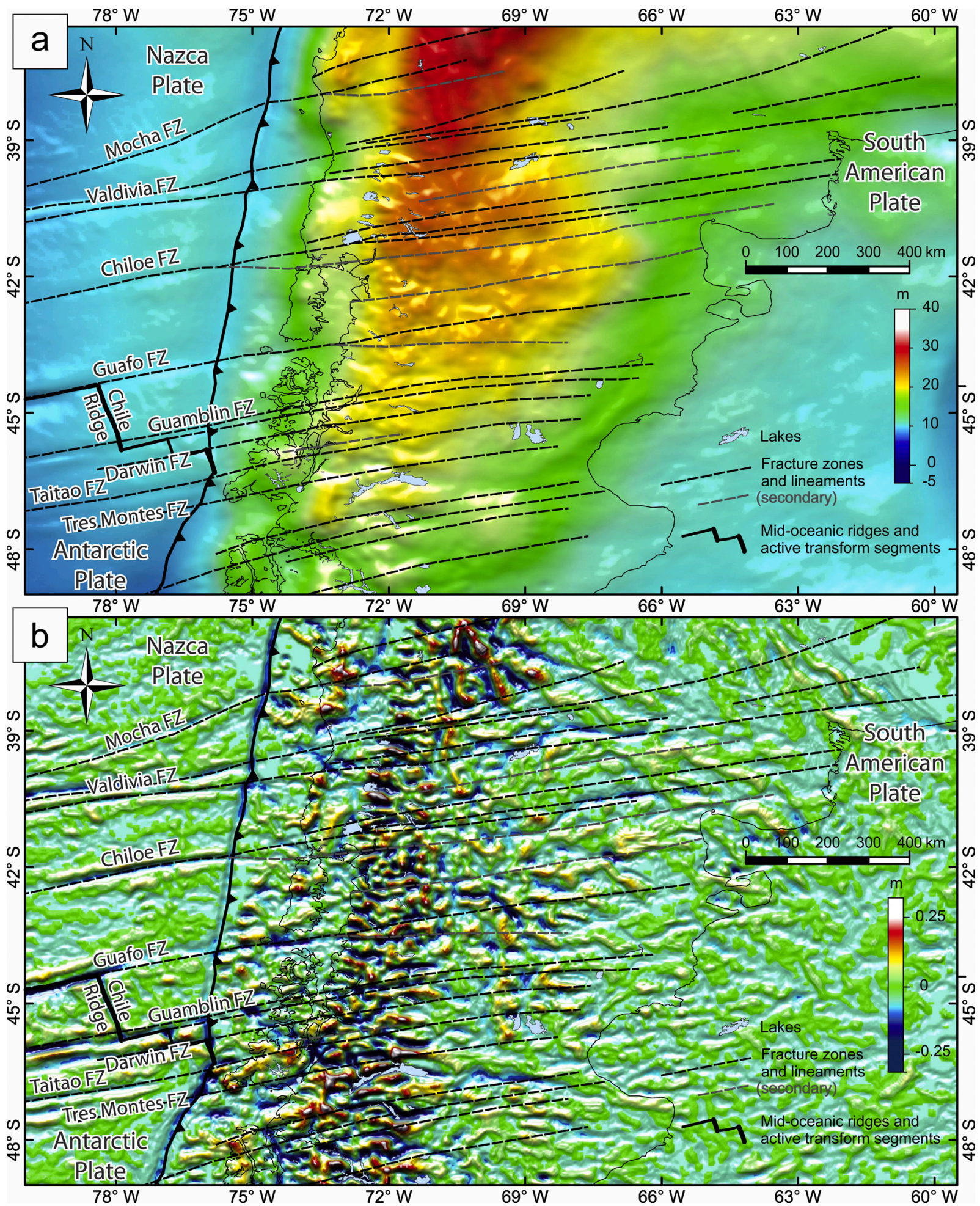

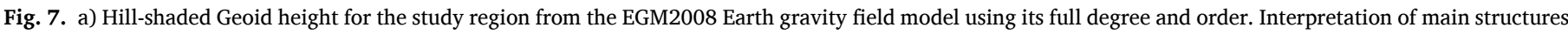

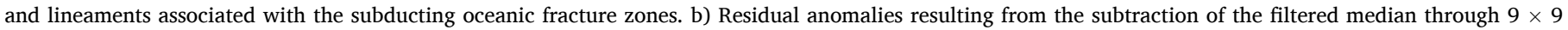
sliding windows to the EGM2008 geoid model. FZ: Fracture zone; Trench and coastline are indicated as a reference.

In Fig. 7a, we show a representation of the geoid undulations from the EGM2008, relative to the WGS84 ellipsoid, at the study region. The geoid model reflects the mass distribution below the Earth surface and contains the effects of topography which is included in its shortwavelength deflections (Fig. 7b). Therefore, the geoid expression analysis is particularly important because it is directly related to the forces required to maintain topography (Turcotte and Schubert, 2014).
Here, the geoid shape data and residual anomalies compared to the relief anomalies show several morphological correlations. In Fig. 7a, the forearc shows low positive values ranging from 10 to $20 \mathrm{~m}$, with its highest values concentrated at areas near the Chilean coast, where the Coastal Cordillera is developed. In contrast, decreasing values are observed towards the trench related to the presence of slope basins, the subduction channel, and the trench itself. The lowest values in this 

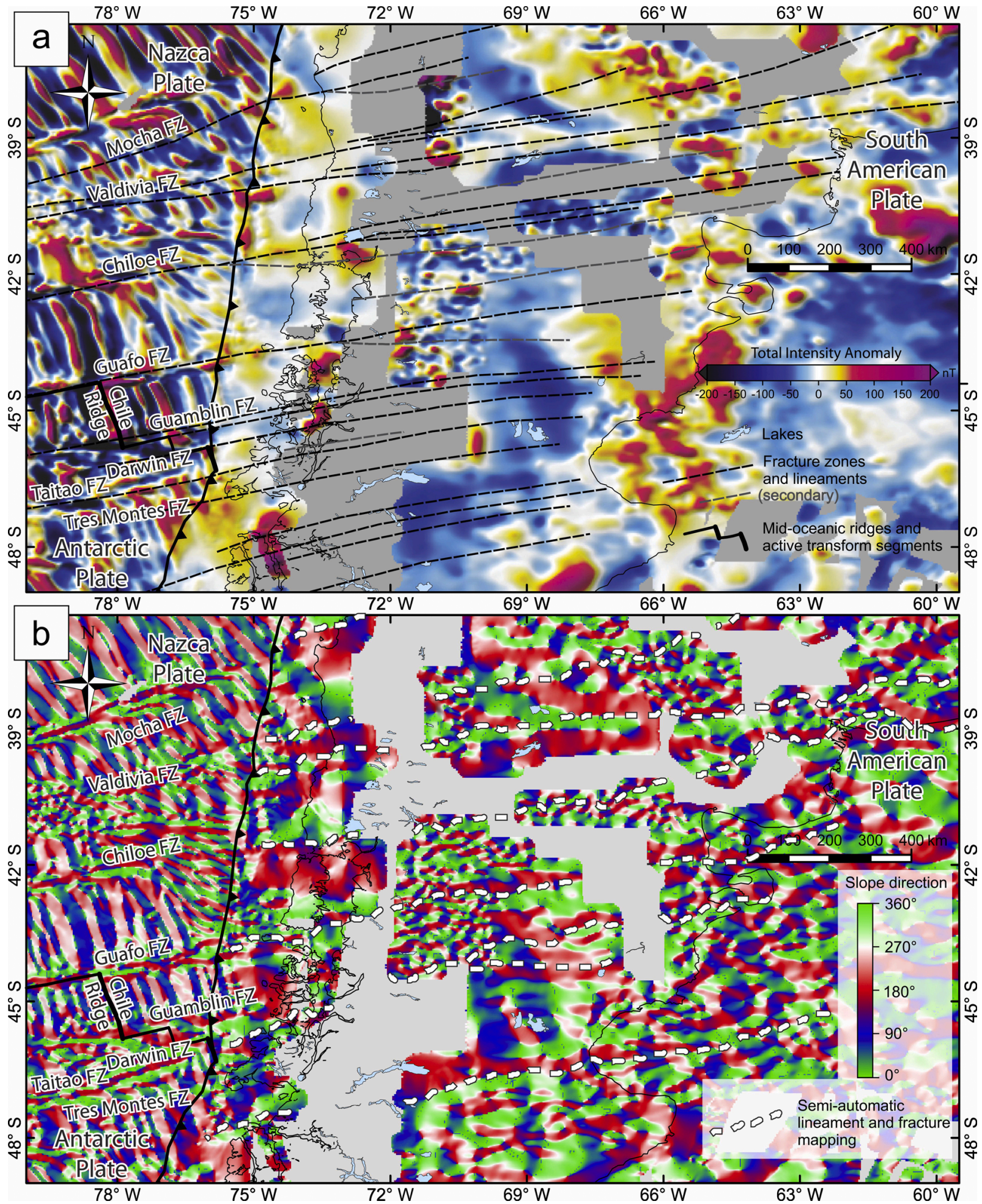

Fig. 8. a) Detail of the map of the magnetic total intensity anomaly from Maus (2009) (see Fig. 4). This global magnetic anomaly grid shows for this region how short-wavelength anomalies coincide with the trends of the interpreted damaged zones associated with the propagation of fracture zones through the continental crust. b) Slope direction map of the magnetic anomaly grid and applied semi-automatic lineament mapping (least-cost-path algorithm, Thiele et al., 2017) to the main FZs related anomalies.

region are found south of Taitao peninsula (CTJ), where there is a relative low (less than $+10 \mathrm{~m}$ ) in the geoid related to a wide accretionary prism developed in the Patagonian forearc after its interaction with the rough bathymetry of subducted Chile Ridge segments (Maksymowicz et al., 2012; 2015). The Patagonian Cordillera (or the main Andes) shows as expected its highest values to the north (more than $+25 \mathrm{~m}$ ) that gently decrease up to $15 \mathrm{~m}$ towards the south. This mountain chain shows a clear $\mathrm{N}-\mathrm{S}$ anomaly trend towards its western drainage divide. While to the retroarc and foreland zone, a broad anomaly zone is developed and delimited by geoid heights around 25 and $20 \mathrm{~m}$. Within this sector, smaller trends in the geoid undulations can be depicted responding to NNW oriented ranges to the north of $40^{\circ} \mathrm{S}$ and $\mathrm{N}$ - oriented 
trends to the south responding to mountain ranges developed at the broken foreland zone. This pattern seems to respond to the interaction with the subducted oceanic crust at depth and variable fabric orientation north and south of the Valdivia FZ, which are depicted in the magnetic anomaly map of Fig. 8.

Therefore, the magnetic anomaly map of Fig. 8 provides insights into the correlation of the oceanic crust fabric with the observed structures on the continental crust. In the forearc area, wide patches of low total magnetic anomaly intensity (up to $-50 \mathrm{nT}$ ) are observed between the segments defined by FZs, especially at the trench slope areas between Valdivia, Chiloe, Guafo and Guamblin FZs, whereas in the zones of FZs intersections relatively smaller anomalies of variable intensity (between
+50 to $-50 \mathrm{nT}$ ) are found (Fig. 8a). To the south of the CTJ, a wide positive anomaly (up to $+100 \mathrm{nT}$ ) is developed, which is related to features of the subduction of the Chile active ridges and the slab window generation (Breitsprecher and Thorkelson, 2009; Guillaume et al., 2009; Russo et al., 2010). To the retroarc and foreland zones, several short-wavelength anomalies are aligned with the interpreted lineaments, while wider anomaly lows are delimited in extent by the locations of the FZs related features. In Fig. 8b we perform a semi-automatic lineament mapping procedure (Thiele et al., 2017) over a slope direction colored map of the magnetic anomaly grid. The least-cost-path algorithm developed by Thiele et al. (2017) allows semi-automatic mapping of structural features in remote sensing images and in geophysical grids
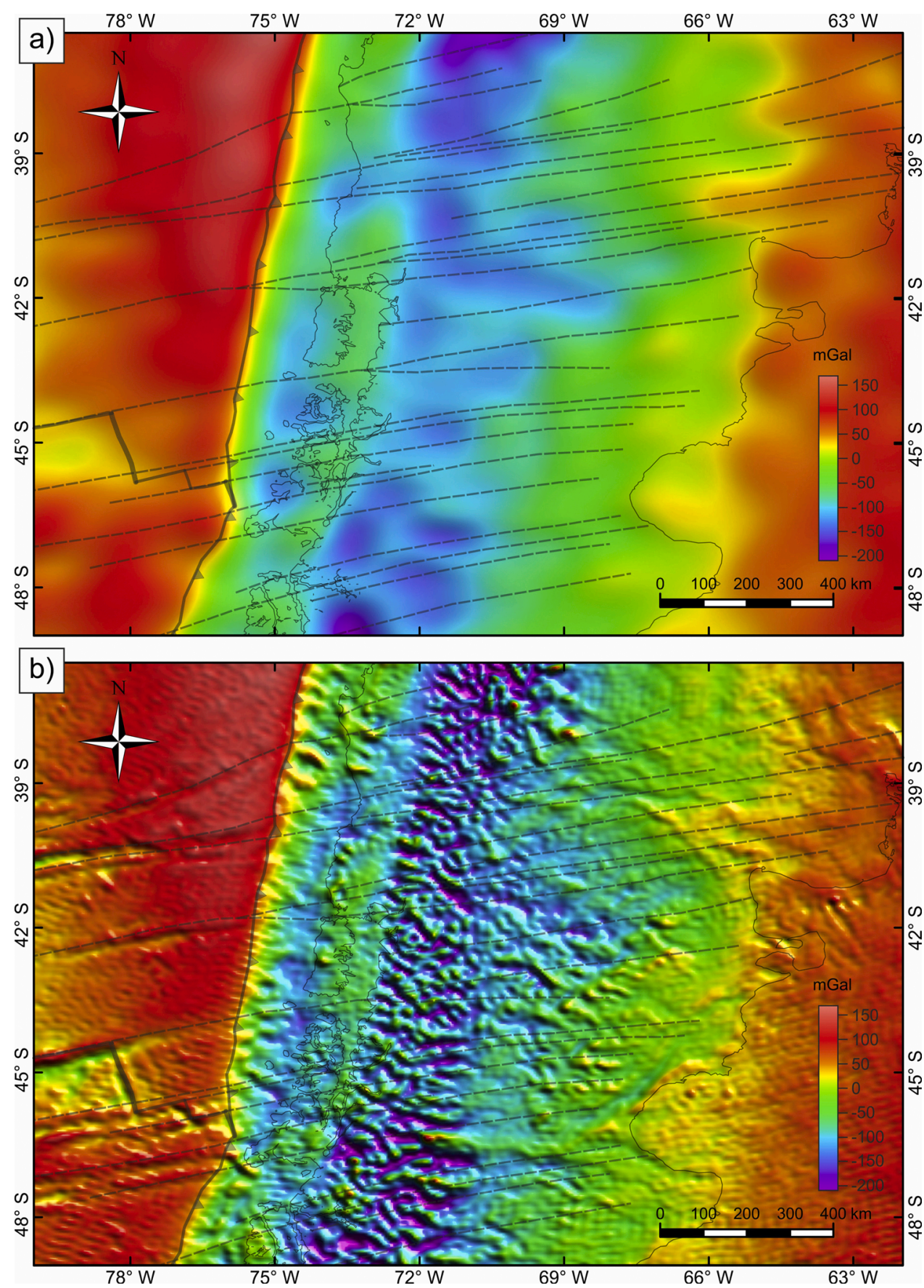

Fig. 9. Topography corrected gravity anomaly from: a) satellite only model GO_CONS_GCF_2_DIR_R5 from Bruinsma et al. (2013), b) EGM2008 (Pavlis et al., 2012). The different FZs over the Nazca Plate and their prolongation over the South American Plate can be identified in the EGM2008 model (b), while the GOCE model (a) presents a long wavelength signal precluding their identification. 
following cost minimum paths to reach control points, usually at the beginning and at the end of the trace. The resulting major lineament mapping highlights the ENE pattern visually enhanced by the slope direction colored map.

\section{Segmentation of the continental crust through the southern Chilean subduction zone using Earth gravity field models}

We calculated the gravity anomaly (Ga) (Fig. 9) and the vertical gravity gradient (Tzz) (Fig. 10) from EGM2008 model (Pavlis et al., 2012) and from GOCE (GO_CONS_GCF_2_DIR_R5, Bruinsma et al., 2013) in a geocentric spherical coordinate system at the calculation height of $7000 \mathrm{~m}$ to ensure that all values were above the topography. Both were calculated on a regular grid with a cell size of $0.05^{\circ}$, with different degree and order of the harmonic expansion for each model (see Table 1), allowing different spatial resolutions and feature recognition

Table 1

Spatial resolution and recognition depths for different gravity model configurations.

\begin{tabular}{lll}
\hline Degree/Order $\mathrm{N}$ & $\begin{array}{l}\text { Spatial resolution } \\
\lambda / 2=\pi \mathrm{R} / \mathrm{N}_{\max }[\mathrm{Km}]\end{array}$ & $\begin{array}{l}\text { Recognition depth } \mathrm{Z}_{\mathrm{l}}[\mathrm{Km}] \\
\text { for Tzz }\left(\mathrm{H}_{\text {calc }}=7 \mathrm{~km}\right)\end{array}$ \\
\hline GO_CONS_GCF_2_DIR_R5: & 66.72 & 20.98 \\
300 & & \\
EGM2008: 2159 & 9 & 3 \\
EGM2008: 720 & 27.5 & 8.8 \\
EGM2008: 360 & 55.5 & 17.5 \\
\hline
\end{tabular}
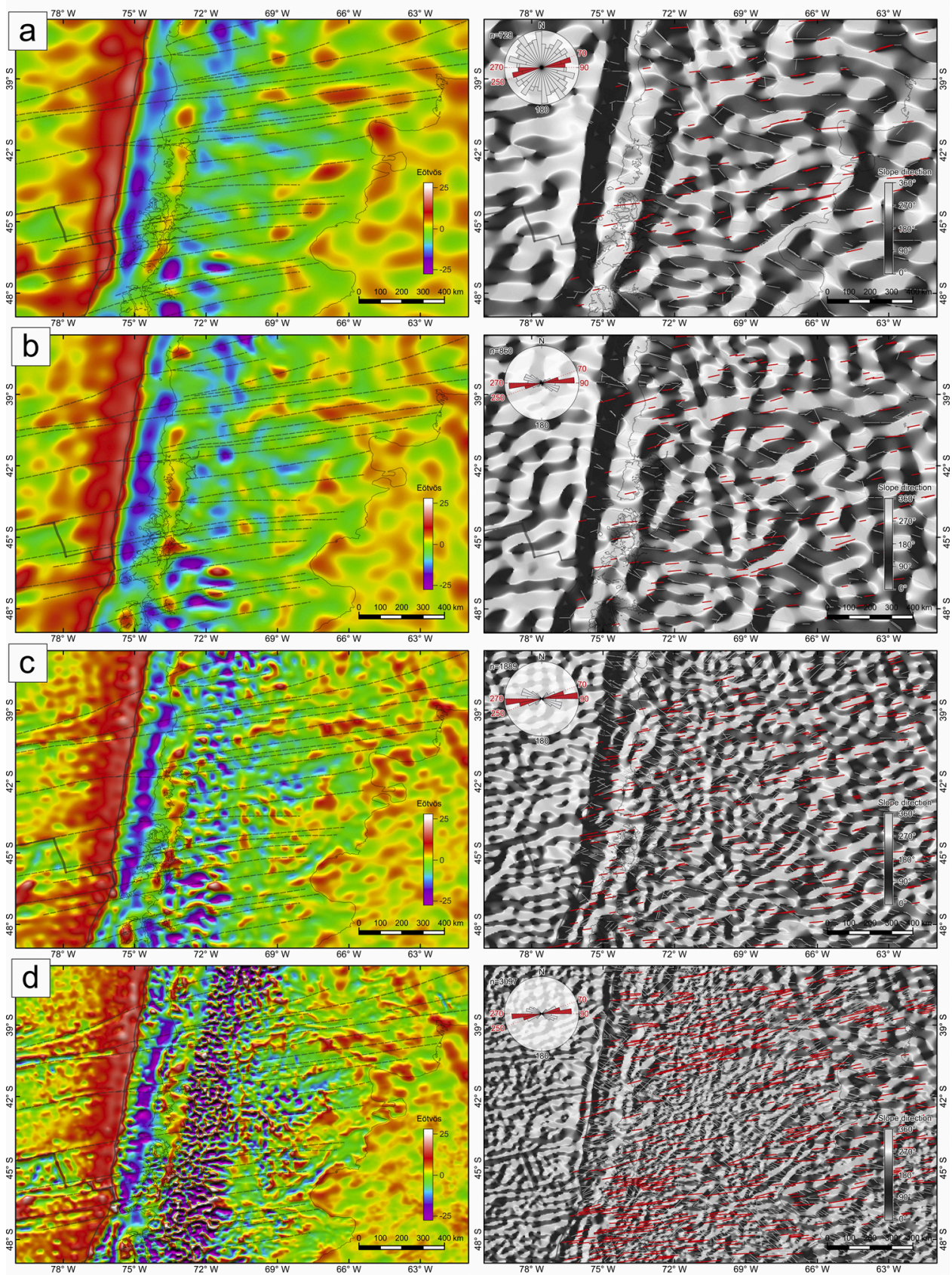

Fig. 10. Left: Topography corrected vertical gravity gradient (Tzz); and Right: Automatic lineament detection solutions obtained with the pyLEFA software (Shevyrev, 2018, 2019) over slope direction maps of the Tzz grid. From: a) GOCE satellite-only model GO_CONS_GCF_2_DIR_R5 from Bruinsma et al. (2013) (up to N = 300), b) EGM2008 (Pavlis et al., 2012) $(\mathrm{N}=360), \mathrm{c})(\mathrm{N}=720), \mathrm{d})(\mathrm{N}=2159)$. Table 1 shows the spatial resolution and the feature recognition depth for each model. 
depths (Álvarez et al., 2016a). The topographic effect was removed from the fields in order to eliminate the correlation with the topography (Álvarez et al., 2013). The topographic correction amounts up to tens of Eötvös for the Tzz, being higher over the maximum topographic elevations (e.g., the main Andes) and lower over the topographic depressions such as the Chilean Trench.

The combined use of satellite-only models as those derived from GOCE and merged ones as EGM2008 (considering their best individual qualities), has been already tested in different studies (Braitenberg et al., 2011; Álvarez et al., 2012, 2014, 2015, 2016a, 2016b). The most reliable areas to apply the EGM2008 model are offshore, foreland and forearc regions (Álvarez et al., 2016b). The GOCE model (DIR_R5) is more appropriate than the EGM2008 model in those regions with rugged topography, as in hinterland regions. Despite its lower resolution it has a more homogeneous precision. Results obtained by means of the EGM2008 model will be analyzed and compared to GOCE, in order to solve the different anomalies in greater detail.

The vertical gravity gradient (Tzz) (Eötvös $=10^{-4} \mathrm{mGal} / \mathrm{m}$ ) highlights shallow density bodies allowing to delineate the location of an anomalous mass with better detail and accuracy than the gravity anomaly (Braitenberg et al., 2011). The spectral power of the Tzz signal is pushed to higher frequencies, resulting in a signal more focalized to the source than the gravity anomaly itself (Li, 2001). Therefore, the combined use of Tzz and Ga allows the detection of the edge of geological structures and to distinguish the signal due to a smaller superficial density variation from an extensive deeper mass (by using Tzz). It also permits to study regional signals and deeper sources (by means of $\mathrm{Ga}$ ). A positive gradient is related to relative denser bodies while negative values are related to less dense bodies. Therefore, abrupt changes in the signal may indicate a high-density contrast within the crust related to geological features.

In Fig. 9, the gravimetric effect of the oceanic Nazca Plate shows increasing values to the $\mathrm{E}$ - and $\mathrm{N}$ - directions as ocean floor ages, whereas the Chile Rise that marks the boundary between the Nazca Plate to the north and the Antarctic Plate to the south presents a low gravity signal ( $-25 \mathrm{~m} \mathrm{Gal}$ ). Low gravity values (less than $-150 \mathrm{mGal}$ ) along the Andean axis detected in the Ga from GOCE (Fig. 9a) and from EGM2008 (Fig. 9b) are related to the negative gravimetric response of the Andean roots. In this context, the outer rise of the downgoing Nazca Plate presents a positive gravity anomaly higher than $+100 \mathrm{mGal}$ (Fig. 9) and more than +15 Eötvös Tzz (Fig. 10). It decreases continuously to the south reaching a relative minimum near the CTJ, where the oceanic plate is younger. Also, the different FZs exhibit a well-defined ENE gravity gradient, since they constitute highly serpentinized and fractured oceanic crust that separates different slab segments with contrasting ages (Contreras-Reyes et al., 2008). The vertical gravity gradient (Tzz) highlights the irregular oceanic floor along the Chile Ridge and FZs (Fig. 10). Whereas over the continental crust, with the Tzz signal it is possible to depict the path of lineaments related to the different FZs, as the segmentation persists with increasing depth of analysis (i.e. truncation of degree/order $\mathrm{N}$ of the harmonic expansion) (Fig. 10). These ENE trending linear features are also detected through the resulting solutions of an automatic lineament processing with the pyLEFA software (Shevyrev, 2018, 2019) plotted over slope direction maps of the Tzz grids.

The region comprised between the trench and the coastline presents low Ga and Tzz indicating the existence of low density materials filling continental slope basins and a trench buried under thick sediment infills (up to $2.5 \mathrm{~km}$ thick; Bangs and Cande, 1997; Sandwell and Smith, 1997; Laursen et al., 2002; Ranero et al., 2006; Völker et al., 2013). Here, the inception of the different FZs affects the sediment distribution, being detected by perturbations of the Tzz signal in GOCE (Fig. 10a) and EGM2008 (Figs. 10b, c, d). Moreover, between the Coastal Cordillera and the Patagonian Andes a series N-S aligned anomalies of relatively higher $\mathrm{Ga}$ (up to $-25 \mathrm{mGal}$ ) which coincide with Tzz highs (up to +10 Eötvös) is observed (Fig. 10a, b, c). These anomalies could be related to density properties within the paleo-accretionary prism (Willner et al., 2004; Glodny et al., 2006) and/or to an attenuated Moho in the Longitudinal Valley (Central Depression) (Dzierma et al., 2012b; Encinas et al., 2016). Furthermore, the Tzz signal in the retroarc zone allows depicting features coincident with mountain ranges and sedimentary basins developed in the Andean front, between $72^{\circ}$ and $69^{\circ} \mathrm{W}$, as a series of highs and lows delimited in their latitudinal extent by the prolongation of the FZs. Finally, to the east, more complex signals can be depicted that also show an ENE controlled pattern of Tzz anomalies at the foreland zone (Fig. 10).

\section{Segmented exhumation patterns in relation to the geology of the North Patagonian Cordillera}

The spatial correlation of rugged terrain, geopotential field anomalies, outcrop distribution and high erosion rates $(>0.5 \mathrm{~mm} / \mathrm{yr})$ are identified in specific areas such as the North Patagonian Cordillera (Fig. 11). One of the main characteristics of the main Andean Cordillera at these latitudes is the exposure of the northern part of the MesoCenozoic Patagonian Batholith (NPB; North Patagonian Batholith) (Hervé et al., 1993; Pankhurst et al., 1999; Castro et al., 2011) (Fig. 11a). From the compiled geology database of the Neogene intrusions of the $\mathrm{NPB}$, we can observe an along-strike variation (N-S) of their surficial exposure (Fig. 11a). This N-S pattern interferes with the branches of the LOFZ. The LOFZ is a conspicuous feature, along the cordilleran axis, which controls the W-E exhumation pattern across the NPB (Thomson, 2002; Thomson et al., 2010; Adriasola et al., 2006). From an overall perspective, the Neogene intrusive exposures of the NPB coincide with zones of intermediate relief (up to $1 \mathrm{~km}$ ) compared to the high relief pattern associated with the Mesozoic batholith exposures (up to $1.4 \mathrm{~km}$ ) (Fig. 11b). From this local relief analysis, an abrupt change in relief is observed at the intersection of the Chiloé FZ with the main Cordillera, going from average relief values of $\sim 750 \mathrm{~m}$ towards the north to values of $>1000 \mathrm{~m}$ towards the south (Fig. 11b).

Another approach for the estimation of exhumation and erosional cordilleran patterns is the computation of the geophysical relief (Small and Anderson, 1998; Champagnac et al., 2007), which is different from the "ordinary" relief described in previous sections. As defined by Small and Anderson (1998), the geophysical relief describes the eroded volume of valleys or entire mountain ranges derived from the difference between the actual surface heights and the interpolated surface connecting the highest points in the current landscape. To obtain it, we extracted a smoothed surface of the summit flats (highest points with less than 0.2 of slope values) through a $5 \mathrm{~km}$ moving window from the digital elevation model SRTM v4.1 (Jarvis et al., 2008), which was previously filtered from volcanic edifices. Then, we obtained a geophysical relief map by subtracting off the original DEM topography to the summit flats generated surface. From the resulting map (Fig. 11c) we can observe a series of highly eroded valleys of $>1500 \mathrm{~m}$ of geophysical relief which are developed south of $41^{\circ} \mathrm{S}$, whereas, towards the north, the values range between 1000-1250 m. Also, several parts of these highly eroded valleys show ENE preferred orientations. Then, to observe the long-wavelength effects ( $>100 \mathrm{~km}$ length) of the erosional patterns we performed a computation of the isostatic rebound to the erosion (Fig. 11d) obtained from the hypothetical flexural response of the lithosphere to the missing mass depicted in the geophysical relief map. Using the gFlex software (Wickert, 2016), which uses finite difference solutions to simulate the bending of an elastic plate to an imposed load, we calculated the flexural isostatic response to the erosional unloading. The parameters used in the solution of the Fig. 11d are: Te (effective elastic thickness of the lithosphere) $=5 \mathrm{~km} ; \nu$ (Poisson's ratio $)=0.25 ; \rho_{\mathrm{c}}$ (density of the crust) $=2700 \mathrm{~km} / \mathrm{m}^{3} ; \rho_{\mathrm{m}}$ (density of the mantle) $=3300 \mathrm{~km} / \mathrm{m}^{3}$. Flexural isostatic response to erosional unloading is strongly dependent on the effective Te of the lithosphere, therefore we explored Te values ranging between 5 and $25 \mathrm{~km}$. With a Te value of $5 \mathrm{~km}$, the maximum vertical movement is $891 \mathrm{~m}$ developed near 


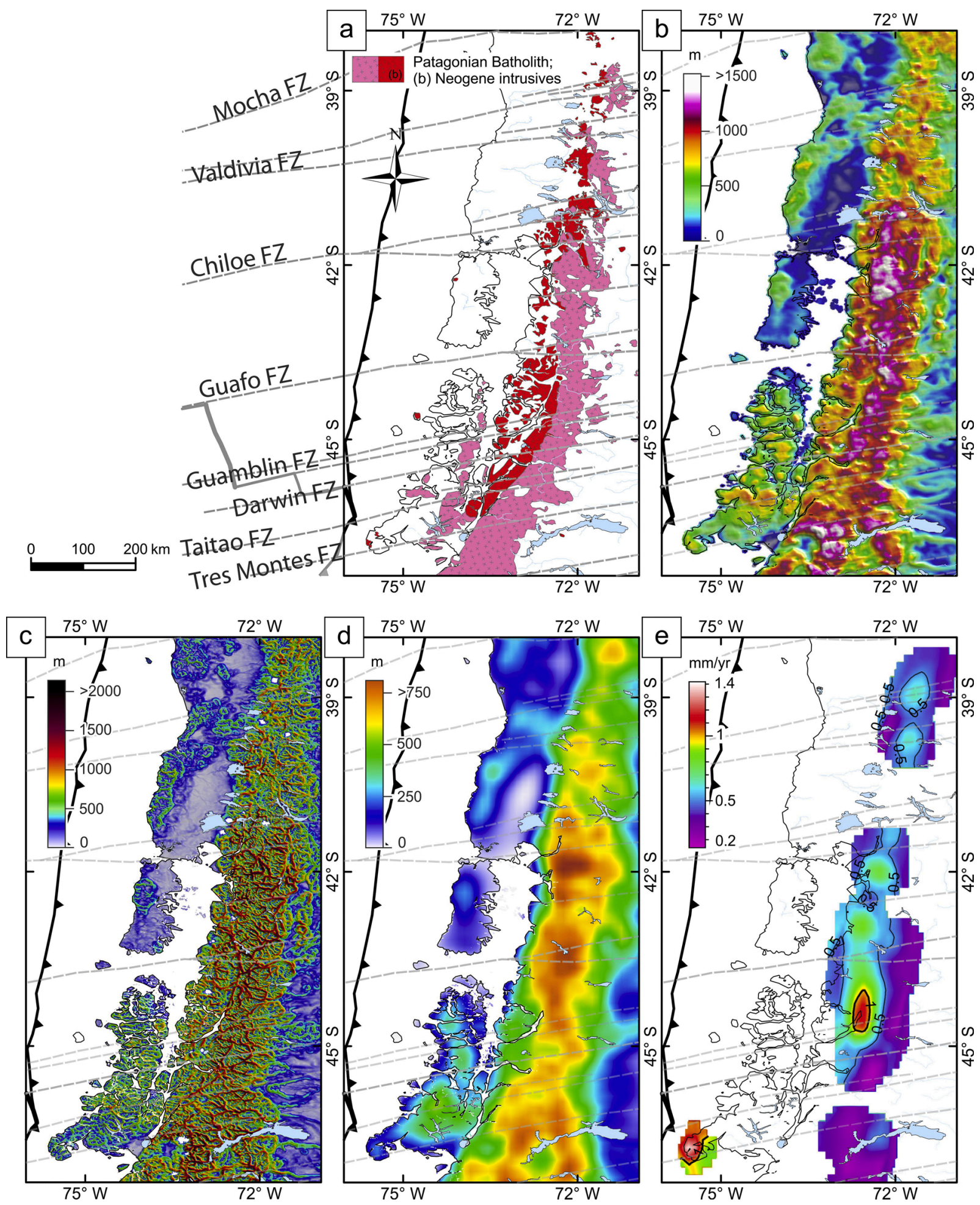

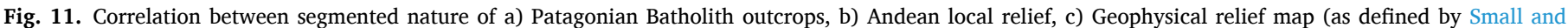

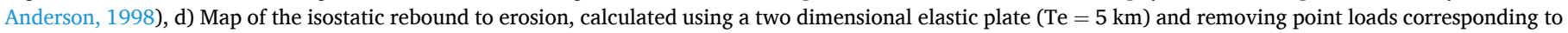
the geophysical relief missing mass (see text for details), and e) average exhumation rates for the last 2 Myr (from Herman et al., 2013).

the center of a deflection bellow the Chiloé FZ (Fig. 11d), whereas with a Te value of $25 \mathrm{~km}$ is $662 \mathrm{~m}$. Although with small Te values yield higher vertical movements with steeper gradients, the patterns and shapes of the flexural anomalies differ little in its distributions (see Supplementary material).

In agreement, the exhumation rates taken from thermochronometric and geobarometric data inversion from Herman et al. (2013) and
Herman and Brandon (2015) show a spatial correlation at the Andean axis with the erosional patterns or the different segments delineated by the FZs themselves (Fig. 11e), even though long-wavelength spectra ( $>100 \mathrm{~km}$ length) of the erosion anomalies are related to climatic factors (Montgomery et al., 2001; Thomson et al., 2010; Herman and Brandon, 2015). The short-wavelength ( $<100 \mathrm{~km}$ length) along-strike exhumation rates variation might correspond to local features like localization 
of erosion due to rain barriers and glacial processes related to specific mountain building processes. The exhumation pattern of Fig. 11e shows that short-wavelength anomalies correlate well with the intersection of two main branches of the Valdivia fracture system. Broader anomalies could be associated with and delimited by the Chiloe, Guafo, Guamblin and Darwin FZs. The broader anomalies like the one delimited between Guafo and Guamblin FZs (Fig. 11e) are developed in an area of significant offset of the oceanic crust. These areas show high bathymetric relief with respect to the northern portions due to their higher buoyancy (see Figs. 4 and 6). Therefore, sustaining Andean topography and leading to higher exhumation rates in these areas.

The integration of these data shows that the broader patterns (i.e. long-wavelength anomalies) of cordilleran exhumation and relief production were climatically driven and enhanced in Plio-Quaternary glacial times. Although, some minor patterns (i.e. short-wavelength anomalies) of valley generation and exhumation anomalies coincide with the orientation and projections of the FZs (Fig. 11) and could be interpreted as a consequence of FZs related structuration, local uplift, or enhanced erosion after glacial preservation of the orogenic landscape (see Thomson et al., 2010).

\section{Overall fracture zones segmentation across Northern Patagonia $\left(36^{\circ}\right.$ to $\left.48^{\circ} \mathrm{S}\right)$}

The general pattern of FZs that has been subducted since at least the last $18 \mathrm{Myr}$ essentially at the same intersection points has produced several geological imprints reflecting this subduction dynamics. Here we show a regional outcrop analysis in order to verify the apparent control of these oceanic structures on upper plate morphology. Therefore, we present a geological map compilation based in a 1:1000000 scale in a relative uniform grid (Fig. 12). This map was based in several sources such as the 1:1000000 geological map of Chile (SERNAGEOMIN, 2003), the 1:2500000 of Argentina (SEGEMAR, 1999) and various 1:250000 regional and 1:750000 provincial geological maps of Argentina produced by SEGEMAR. The compilation is also completed by field mapping of different units and Andean structure from Orts et al. (2012); (2015) and from other authors (e.g. Adriasola et al., 2006; Castro et al., 2011; Kay et al., 2006, 2007; Folguera et al., 2015; Giacosa and Márquez, 1999; Giacosa et al., 2010; Rojas-Vera et al., 2014; Ramos et al., 2014; Lagabrielle et al., 2004; among others).

From the geological map of Fig. 12 we can distinguish a pattern in the surface exposure of different geological units. This pattern denotes

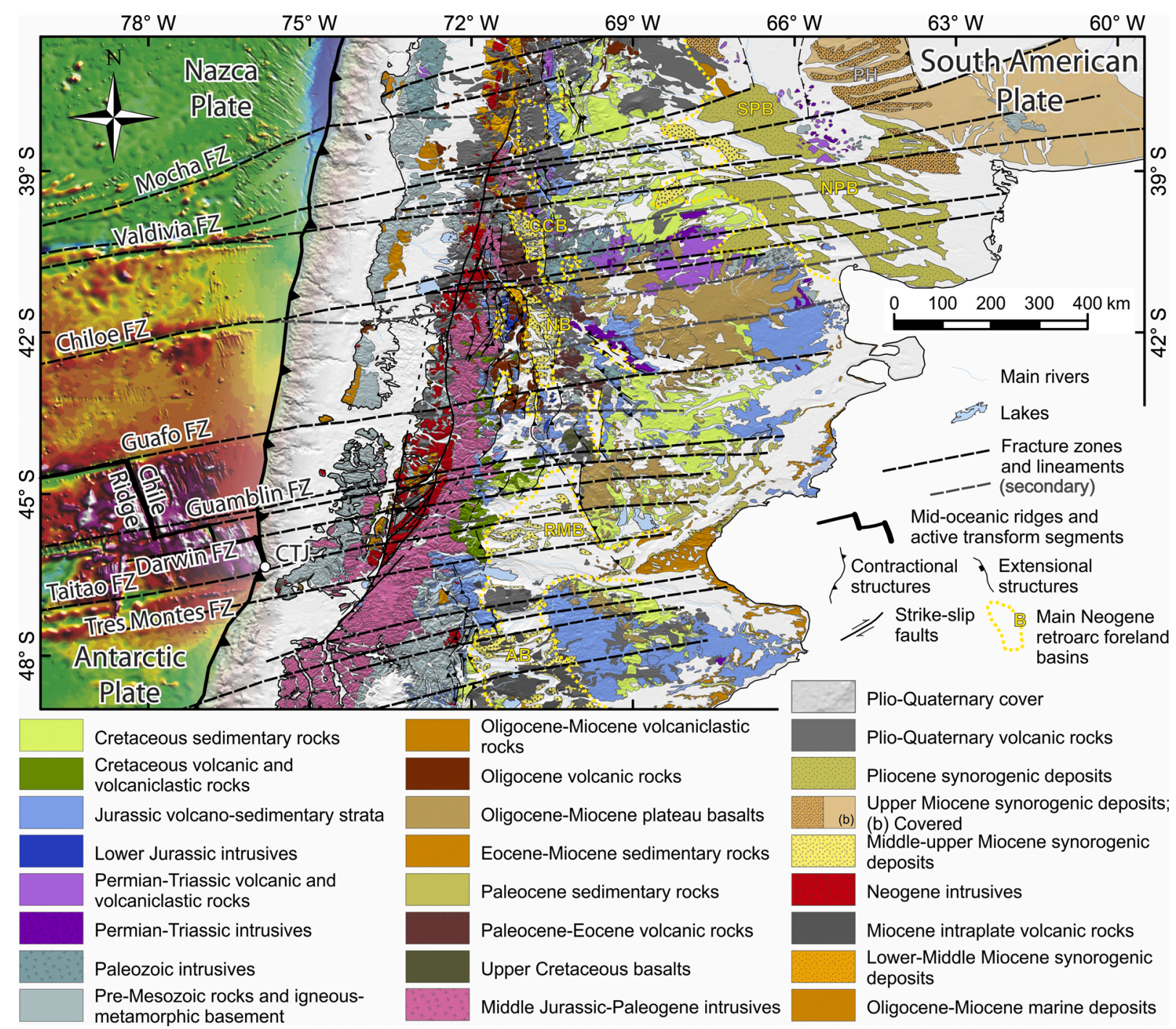

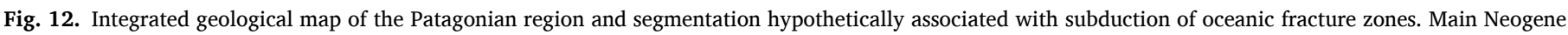

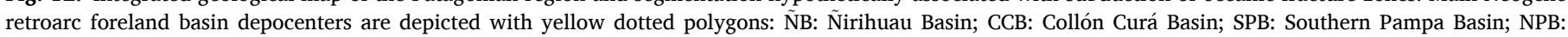

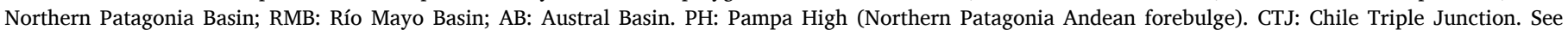
supplementary material for a more detailed and without FZs interpretation version of the map. 
that the shape and areal extent of several geological units are partially controlled by the structural features related to the ENE propagation of the FZs across the continental plate. This control can also be inferred by the distribution of the main Cenozoic basin depocenters (Fig. 12). Also, a more notorious NW-SE Paleozoic-Mesozoic tectonic fabric developed across vast parts of Southern South America may interact with the ENE pattern hindering its detection (von Gosen and Loske, 2004; von Gosen, 2009; Glodny et al., 2006; Pankhurst et al., 2006; Hackney et al., 2006). For example, particular features of the Andean structure depicted in the map, such as the deformational belts of the eastern side of the Andean Cordillera that seem to be partially controlled by this segmentation (Fig. 12). Within the domains defined by the FZs prolongations, different $\mathrm{N}-\mathrm{S}$ deformational belts (relatively parallel to the Andean axis) are developed, where dip-slip displacement dominate as in the Neogene Nirihuau fold and thrust belt (FTB) (Giacosa and Heredia, 2004; Bechis and Cristallini, 2006; Garcia-Morabito et al., 2011; Orts et al., 2015). This belt is circumscribed to the domain defined by Chiloé and Guafo FZs (Fig. 12). Another important deformational belt is the San Bernardo FTB (Homovc et al., 1995; Gianni et al., 2015), which is associated with the domain defined by Guafo and Tres Montes FZs. Moreover, the Andean and Precordilleran sectors are compartmentalized in response to the disposition of the Guamblin, Taitao and Darwin FZs. North of $39^{\circ} \mathrm{S}$ the interaction is more complex due to the anomalous amplitude of the Valdivia FZ fault system and the obliquity of the Mocha FZ (Folguera and Ramos, 2009). This configuration affects the development of post-Oligocene contractional and extensional structures within these deformational belts as in the Neuquén Precordillera (Zamora-Valcarce et al., 2006; Cobbold and Rossello, 2003; Folguera et al., 2010, 2012; Rojas-Vera et al., 2010; Garcia-Morabito et al., 2011; Sagripanti et al., 2015). Associated with this retroarc deformational belts, a series of Neogene foreland basins, such as the Santa Cruz, Río Mayo, Collón Curá, Nirihuau, and restricted depocenters within the Neuquén Basin was developed (Fig. 12; see also Folguera and Ramos, 2011 and Bilmes et al., 2013). In Fig. 12, these basins are depicted as middle-upper synorogenic deposits between $71^{\circ}$ and $69^{\circ} \mathrm{W}$. Particularly, Collón Curá and Ñirihuau basins are circumscribed to the segments defined by Valdivia-Chiloé FZs and Chiloé-Guafo FZs, respectively. Similarly, the Neogene Rio Mayo Basin is developed south of Guamblin FZ and compartmentalized by other several FZs such as Tres Montes FZ among others relatively closely spaced.

Far in the foreland zone at these latitudes $\left(36^{\circ}-42^{\circ} \mathrm{S}\right)$ late Miocene to Pliocene synorogenic units (Northern Patagonia and Southern Pampa basins, sensu Folguera et al., 2015) were deposited and segmented by uplifted N-S blocks such as the Pampa High (Vogt et al., 2010; Nivière et al., 2013; Folguera et al., 2015; Huyghe et al., 2015) which coincide with the location of the present Andean forebulge. These deposits are partially segmented by the ENE features that allow dividing them into different sub-basins (see Folguera et al., 2015). In turn, to the southern-eastern foreland zone, south of the North Patagonian Massif (NPM), scarce thick late Cenozoic synorogenic accumulations are preserved related to the Andean uplift, except for the Rio Mayo Basin and Santa Cruz Formation deposits westwards of the Patagonian Precordillera and Deseado Massif (DM) in the former Austral Basin. Covering those deposits, and vast parts of the Patagonian foreland, extensive but thin gravel mantels gathered in the Rodados Patagónicos (see Martínez and Kutschker, 2011) characterize the Patagonian landscape (represented mostly as Plio-Quaternary cover in Fig. 12). These deposits are related to high-energy fluvial action after the inception of the Patagonian glaciations since late Miocene under cold-arid conditions. Preservation and location of these units seem to be related to long-term erosion patterns and Neogene extra-Andean structures, which are partially controlled by the ENE trending FZs related crustal fabric. Although, in the depicted eastern structures and paleosurfaces the exhumation trend would be negligible to thermochronology studies for their mild exhumation rates (Savignano et al., 2016; Kollenz et al., 2016).

\section{Discussion}

Deformation and differential exhumation in subduction systems have been explained by a variety of factors that include variations in: crustal erosion along the margin, angle of subduction, slab age and width, coupling degree imposed by sediments in the trench and degree of serpentinization of the ocean floor, among other factors (e.g. Vogt et al., 1976; Molnar and Atwater, 1978; Cross and Pilger, 1982; Lamb and Davis, 2003; Gutscher et al., 2000; Schellart, 2008). Andean upper plate deformation broadly correlates with the geometry of the subducting slab as a response to differential shear stresses along the plate interface (Kley et al., 1999; Gutscher et al., 2000). However, the varying deformation styles in the upper plate also correlate with older stratigraphic and structural inhomogeneities such as: sutures or ancient decollements (Kley et al., 1999; Mosquera and Ramos, 2006; Glodny et al., 2006; Pankhurst et al., 2006; Hervé et al., 2007, 2013; Ramos, 2008), previous continental rift transfer zones and basin geometries (Allmendinger et al., 1983; Uliana et al., 1989; Tankard et al., 1995; Ghiglione et al., 2009) and their relation with the mechanical and thermal structure of the continental lithosphere (e.g. Cloetingh et al., 2005; Hyndman et al., 2005).

Even though these controls explain at a continental scale variable morphology, shortening, orogen width and height, exhumation, and sedimentation, North Patagonia case study allows including the sharpen-variable bathymetry of the ocean floor imposed by FZs as an additional factor. This control has been proven as having an effect on short term co- and post-seismic deformation in convergent zones, determining maximum development of rupture zones, although its impact on long term deformations has been barely discussed (e.g. Hackney et al., 2006; Contreras-Reyes et al., 2008; Dzierma et al., 2012a; Bassett and Watts, 2015a, 2015b; Maksymowicz, 2015; Martinod et al., 2016).

We have shown in this work that in a setting characterized by shallow ocean bathymetry such as the case of the North Patagonian subduction system, the FZs delimit panels with contrasting buoyancy and consequently bathymetry. These morphologies generate lateral changes in physical properties of the plate interface such as the coupling degree or thermal weakening due to fluid release (Dzierma et al., 2012a; Moreno et al., 2014; Manea et al., 2014). These lateral variations explain the segmentation of relief, allowing us to identify segments with differential main topography separated by high relief gradients, magnitude of exhumation and consequently surface geology and probably also crustal thickness as suggested by geoid and mixed terrestrial-satellite gravity models.

The analysis of gravity gradients allowed us to observe the pervasive nature of this segmentation mechanism. The crustal discontinuities related to these lineaments are discernible up to $18 \mathrm{~km}$ depth (Fig. 10). This is indicative of deep-seated crustal wrenching or lateral accommodation zones also expressed in the diffuse surficial nature since these lineaments generally do not correspond to single faults at surface, but are narrow to broad damaged zones (e.g. Allmendinger et al., 1983; Jacques, 2003). These lineaments broadly delimit the lateral extent of orogen-parallel deformational belts and partially control exhumational and erosional patterns across the Patagonian platform. This can be observed in the performed regional geological mapping compilation (Figs. 11 and 12) and its comparison with the exhumation rates in specific areas such as the Patagonian Cordillera (Fig. 11).

\subsection{The role of previous crustal anisotropies in Patagonia during the late Cenozoic Andean deformation}

The heterogeneous rheological behavior of the Patagonian continental lithosphere due to pre-existing structures such as Paleozoic major sutures zones and decollements would have favored the location and propagation of the Andean deformation through the Patagonian crust at $39^{\circ}-40^{\circ} \mathrm{S}$ (Mosquera and Ramos, 2006; Pankhurst et al., 2006; Ramos, 
2008, 2009; Hervé et al., 2007, 2013). Also, rifting transfer zones developed during early stages of Gondwana break-up (Uliana et al., 1989; Tankard et al., 1995; Jacques, 2003; Ghiglione et al., 2009) could promote the propagation of fractures exploiting preexisting zones of weaknesses in the continental crust.

Moreover, inherited rheological continental structure as seen in variable effective elastic thicknesses of the lithosphere (Te) (e.g. Tassara and Yáñez, 2003; Tassara et al., 2007; Pérez-Gussinyé et al., 2007; Álvarez et al., 2016b) could facilitate and even control the fracture propagation. These changes in elastic thickness (Te) are related to the inherited continental fabric, the crustal composition, age and thermal state. Consequently, several Te estimates (e.g. Tassara and Yáñez, 2003; Tassara et al., 2007; Pérez-Gussinyé et al., 2007; Álvarez et al., 2016b) show lateral variations through the Patagonia Phanerozoic platform when compared to older cratonic regions of South America, showing the highest Te values. However, within the Patagonia region anomalous Te values can be found at the North Patagonian Massif and in Deaseado Massif depicting a thermomechanical heterogeneity in this region. These varying Te values reflect the flexural properties of the lithosphere and therefore would also modulate the isostatic response to loading and unloading such as the hypothetical rebound to erosion of Fig. 11d.

Patagonia experienced successive magmatic events since late Paleozoic. These magmatic processes such as the development of Choiyoi (Permo-Triassic) and Chon Aike (Jurassic) magmatic provinces (Kay et al., 1989; Pankhurst and Rapela, 1995) and arc magmatism followed by widespread tectono-magmatic events in Cenozoic times (Muñoz et al., 2000; Rapela et al., 2005; Kay et al., 2006; Aragón et al., 2013; Echaurren et al., 2016) affected the Patagonian region. Therefore, the protracted lithospheric high thermal flux related to these magmatic events could have caused thermal weakening across Patagonia. As a consequence of this, brittle-ductile strength variations at depth could have developed, facilitating the propagation of the deformation towards the foreland area (e.g. Cloetingh et al., 2005; Hyndman et al., 2005; Echaurren et al., 2016). These deformation patterns and widening of the orogenic wedge are broadly and locally affected by the slab morphology such as slab dip angle variations in time at different latitudes across the Andes (see Martinod et al., 2020 and references there in).

\subsection{Implications of plate kinematics over crustal deformation}

An important change in tectonic conditions since 25 Myr ago was caused by plate reorganization in the Pacific Ocean (Cande and Leslie, 1986). This was followed by an increase in convergence rate reaching a maximum velocity of the Nazca Plate relative to the South American Plate between 20 and $10 \mathrm{Ma}$ (Somoza and Ghidella, 2005; Sdrolias and Müller, 2006; Quinteros and Sobolev, 2013; Wright et al., 2016), with a vector with an almost constant orientation of $\sim \mathrm{N7} 8^{\circ} \mathrm{E}$ afterwards. These conditions may have favored long-term deformational processes in Patagonia region in the Neogene to Quaternary period. In fact, rapid plate motion changes could have caused significant deformations in plate interiors affecting the crustal structure generating long-term anisotropies that could control the subsequent tectonic scenarios (e.g. Matthews et al., 2012; Iaffaldano and Bunge, 2015).

An important dynamic process occurring at the Patagonian subduction system is the strain partitioning and localized seismicity due to oblique subduction. Therefore, another factor to be considered is the evolution of the Liquiñe-Ofqui Fault Zone (LOFZ) (Hervé, 1994; Cembrano et al., 1996; Lavenu and Cembrano, 1999; Thomson, 2002; Hernandez-Moreno et al., 2014). This fault system accommodates significant deformation related to oblique stresses since late Miocene (Lavenu and Cembrano, 1999; Hernandez-Moreno et al., 2014), whereas near-normal to the trench stresses would be transmitted into the forearc and retroarc regions regarding this feature (Folguera and Ramos, 2002). Therefore, the local exhumation gradients (Fig. 11) are partially controlled by this feature in combination with the dynamics of the subduction of active ridge segments, the migration the CTJ and climatic factors (Thomson, 2002; Thomson et al., 2010; Adriasola et al., 2006; Herman et al., 2013; Herman and Brandon, 2015). In the vicinity of the CTJ shear wave splitting studies show ENE trends related to the upper mantle flow from west to east through the slab window (Russo et al., 2010). From this ongoing process, the upper plate crustal structure south of the CTJ registered the subduction of different segments of the former Chile Ridge at these latitudes (Lagabrielle et al., 2007; Scalabrino et al., 2009; Barberón et al., 2018, 2019). The Andean front at the northern part of the Austral Basin (Fig. 12) have experienced differential growth of eastward advancing thrust systems in Miocene times controlled by enhanced plate coupling driven by the approaching ridge segments (Lagabrielle et al., 2007; Scalabrino et al., 2009; Barberón et al., 2018, 2019). Following the Chile Ridge subduction and subsequent opening of the slab window, a extensional or transtensional tectonic event occurred after $5 \mathrm{Ma}$, reactivating ENE and NNW-trending lineaments (Lagabrielle et al., 2007; Scalabrino et al., 2009). Thus, during the latest Miocene-Pliocene, this foreland region south of the CTJ experienced a period of relief inversion. Consequently, this relief inversion process would be propagating northwards as the Chile Ridge segments continue being subducted as well as the slab window widens beneath the continent (Lagabrielle et al., 2007; Scalabrino et al., 2009; Russo et al., 2010).

\subsection{Upper plate accommodation mechanisms to slab bathymetric features and interface heterogeneity}

The downgoing plate with its segmented fabric, relief anomalies and distribution of sediments along the interplate zone could contribute together since $18 \mathrm{Myr}$ to the upper plate deformation pattern. Here we propose that the upper plate accommodation-response to these slab features could be included as mechanisms of deformation related to morphological and mechanical heterogeneities of the subducted slab at the plate interface (Fig. 13). Therefore, the segmentation of the overriding plate due to the staggered bathymetry of the ocean floor, related to age offsets, could be enhanced thought different shear fracture propagation mechanisms (e.g. Kulander et al., 1979; Atkinson, 1989; Kim et al., 2004) (Fig. 13a, b). In this model, the shear structures may be restricted to the forearc area while the propagating fractures or damage zones individualize crustal segments to the upper-plate interior.

Because of this long-lasting configuration, individualized crustal segments show contrasting exhumation levels, topography and relief, as well as differential patterns of deformation and basin formation. In Fig. 13c, we show how different contrasting deformational domains could be developed in response to the oceanic relief. Extensional structures might develop preferentially across segments of relatively low bathymetry while contractional structures might develop in the retroarc area of highly buoyant subducting slab segments (Fig. 13c). Note that contraction in the retroarc (e.g. Zamora-Valcarce et al., 2006; Rojas-Vera et al., 2014; Garcia-Morabito et al., 2011; Orts et al., 2012) and extension in the forearc can coexist (e.g. Becerra et al., 2013; Encinas et al., 2012, 2016) due to crustal erosion (Fig. 13c and d). Along-strike segmentation could result from different degrees of subduction accretion or erosion in contiguous segments along the Chilean margin (Keppie et al., 2009; Kopp, 2013) (Fig. 13d). These differences in subduction accretion/erosion degree could be related to tectonic processes dependent on sediment supply to the trench and accommodation space associated with the lower plate morphology.

Thermomechanical numerical models (Manea et al., 2014) showed that enhanced production of slab-derived fluids and mantle wedge melts are localized in the areas where the FZs are subducted. This, together with the thermal state related to the subducting slab age (Völker and Stipp, 2015; Rotman and Spinelli, 2014) affect the thermal flux in the forearc and arc settings along and across strike. This thermomechanical segmentation matches the interseismic patterns of locking and creeping zones along the interplate surface, also related to dehydration of serpetinized FZs (Dzierma et al., 2012a; Moreno et al., 2014). At the center of these slab segments, on the interplate zone, asperities and high 

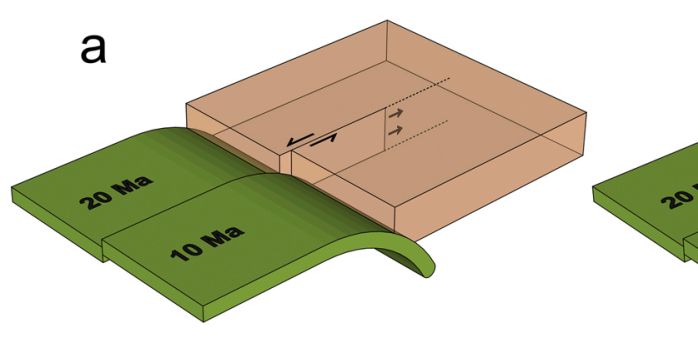

b
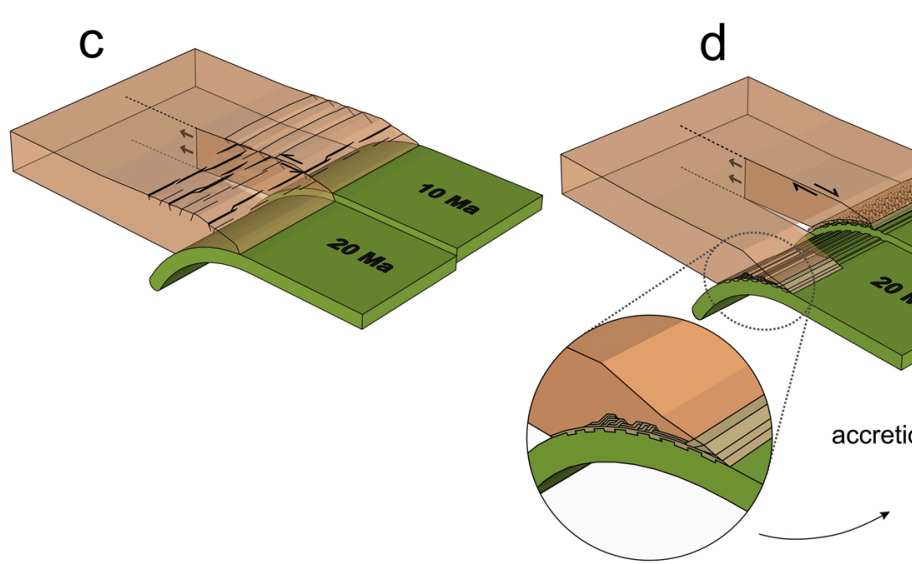

accretion-underplating vs. subduction erosion due to oceanic topography/ accommodation space

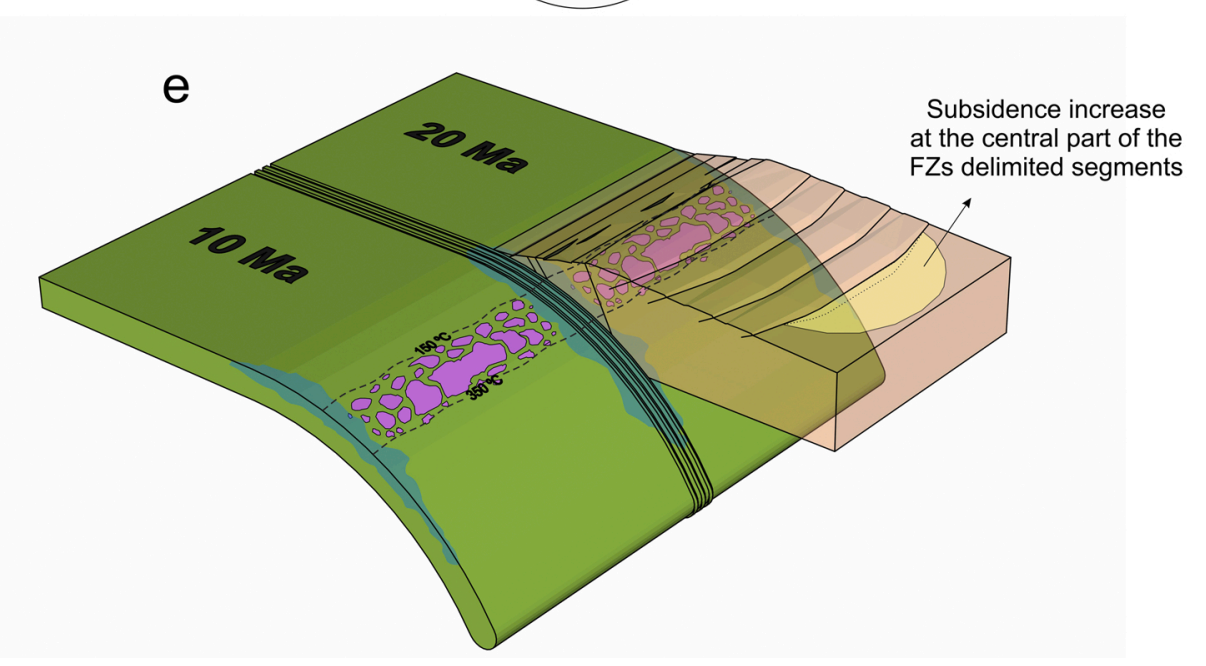

Fig. 13. Schematic cartoons showing proposed upper plate deformational mechanisms due to plate interface heterogeneity and morphology. a) Shear fracture propagation by mode II fracturing. b) Shear fracture propagation by mode III fracturing. c) Differential structural style or behavior across upper plate due to slab segmentation and shear propagation. d) Contrasting mechanical processes of accretionunderplating and crustal erosion. e) Frictional characteristics of the plate interface; pink patches indicating interseismic locked areas and blue areas indicating fluid rich regions related to altered oceanic crust at the FZs resulting in creeping areas with low locking degree. Enhanced upper plate contractional deformation and associated basin subsidence at the central part of the segment is exemplified. For simplification, the sketch does not account for a progressive increase in subduction angle as the oceanic plate becomes older laterally. coupling degree zones associated with low fluid content are concentrated, while to their borders (FZs) the slab will slide more easily (Fig. 13e). Also, the underplating stacking at the subduction channel would be partially controlled by the contrasting pore-fluid pressures and related FZs structures. This segmented behavior during the recurrent seismic cycles would have partially shaped the deformation towards the retroarc area delimiting different deformational domains (Figs. 12 and 13). This segmentation propagated from the interplate zone would have facilitated the tectonic transport of the retroarc fold and thrust belts through brittle-ductile transitions in a thermally weakened crust (see Echaurren et al., 2016). So, these individualized fold and thrusts belts could involve basin subsidence increase towards the central parts of their deformation fronts (Fig. 13e). Although main retroarc foreland basins show that their main depocenters are located between the FZs segments, some erosion related preservation artifacts might occur.

Therefore, models that analyze spatial development of metamorphic, igneous and sedimentary units should take into consideration this additional control and the possibility that surficial expression of certain units could be a consequence of their preservation potential, due to differential subsidence, erosional patterns and contrasting exhumational levels controlled by the subducted ocean bathymetry.

\section{Conclusions}

Through a regional study centered in Northern Patagonia and its interactions with the heterogeneous oceanic Pacific plates in the last 18 Myr, we have individualized particular processes on Andean segmentation related to the spatial-temporal location of the FZs at the Chile trench.

We have identified, through the analysis of relief anomalies, geopotential data, and geological mapping compilation, a series of ENE structural trends or lineaments across the continental crust that could be directly related to the Pacific Ocean floor morphology and enhanced by particular climatic and tectonic history of the Patagonian region.

The compilation and analysis of the seismogenic behavior through earthquake density plots, locking degree, and co-seismic slips allowed linking the plate interface seismological patterns to the observed Andean crustal segmentation. Exhumation rates in the North Patagonian Cordillera from previous works depict denudation anomalies in a similar segmented nature than the ones delimited by FZs prolongations. Improved visualization, though computation of Earth potential fields, has allowed identifying linear trends up to $18 \mathrm{~km}$ in depth across the Patagonian platform. 
From the above data sources and their comparison with the known regional geology and structure recognized at the forearc and retroarc zones, crustal-scale segmentation is identified at distances greater than $500 \mathrm{~km}$ from the trench, where these controls had been initially proposed.

Moreover, based on these observations, we propose a tentative morphogenetic model in which different interactions (erosion/accretion, coupling/creeping, plate accommodation mechanisms) at the plate margin influence the Andean segmentation on the continental crust. Here, individualized crustal segments delimited by FZs would imply different degrees of transmission of shear stresses from the plate interface and therefore lateral variations in the deformation patterns in the upper plate.

Finally, these processes and their implications in crustal structure are worth to be considered in the analyses of deformational patterns of other active and ancient subduction systems.

\section{Author statement}

All persons who meet authorship criteria are listed as authors, and all authors certify that they have participated sufficiently in the work to take public responsibility for the content, including participation in the concept, design, analysis, writing, or revision of the manuscript.

\section{Declaration of Competing Interest}

The authors declare that they have no known competing financial interests or personal relationships that could have appeared to influence the work reported in this paper.

\section{Acknowledgements}

This work was funded by PI UNRN40-A-631, 40-A-798 and PICT2014-1394. We appreciate the comments and suggestions of two anonymous reviewers who helped us to improve the manuscript.

\section{Appendix A. Supplementary data}

Supplementary material related to this article can be found, in the online version, at doi:https://doi.org/10.1016/j.jog.2020.101806.

\section{References}

Adriasola, A.C., Thomson, S.N., Brix, M.R., Hervé, F., Stöckhert, B., 2006. Postmagmatic cooling and late Cenozoic denudation of the North Patagonian Batholith in the Los Lagos region of Chile, $41^{\circ}-42^{\circ} 15^{\prime}$ S. Int. J. Earth Sci. 95, 504-528.

Allmendinger, R.W., Ramos, V.A., Jordan, T.E., Palma, M., Isacks, B.L., 1983. Paleogeography and Andean structural geometry, Northwest Argentina. Tectonics 2, $1-16$.

Álvarez, O., Gimenez, M., Braitenberg, C., Folguera, A., 2012. GOCE satellite derived gravity and gravity gradient corrected for topographic effect in the South Central Andes region. Geophys. J. Int. 190, 941-959.

Álvarez, O., Gimenez, M.E., Braitenberg, C., 2013. Nueva metodología para el cálculo de efecto topográfico para la corrección de datos satelitales. Revista de la Asociación Geológica Argentina 70, 422-429.

Álvarez, O., Nacif, S., Gimenez, M., Folguera, A., Braitenberg, C., 2014. GOCE derived vertical gravity gradient delineates great earthquake rupture zones along the Chilean margin. Tectonophysics 622, 198-215.

Álvarez, O., Gimenez, M.E., Martinez, M.P., Lince Klinger, F., Braitenberg, C., 2015. New insights into the Andean crustal structure between $32^{\circ}$ and $34^{\circ} \mathrm{S}$ from GOCE satellite gravity data and EGM2008 model. In: Sepúlveda, S.A., Giambiagi, L.B., Moreiras, S. M., Pinto, L., Tunik, M., Hoke, G.D., Farías, M. (Eds.), Geodynamic Processes in the Andes of Central Chile and Argentina, 399. Geological Society, London, Special Publications, pp. 183-202.

Álvarez, O., Lince Klinger, F., Weidmann, C., Ariza, J., Giménez, M., 2016a. Modelos globales de gravedad GOCE y EGM2008: su utilidad y complementariedad en la exploración geofísica. Revista de la Asociación Geológica Argentina 73, 134-148.

Álvarez, O., Lince Klinger, F., Gimenez, M., Ruiz, F., Martinez, P., 2016b. Density and thermal structure of the Southern Andes and adjacent foreland from $32^{\circ}$ to $55^{\circ} \mathrm{S}$ using earth gravity Field models. In: Folguera, A., Naipauer, M., Sagripanti, L., Ghiglione, M.C., Orts, D., Giambiagi, L. (Eds.), Growth of the Southern Andes, pp. 9-31.
Aragón, E., Pinotti, L., D'Eramo, F., Castro, A., Rabbia, O., Coniglio, J., Demartis, M., Hernando, I., Cavarozzi, C.E., Aguilera, Y.E., 2013. The Farallon-Aluk ridge collision with South America: implications for the geochemical changes of slab window magmas from fore- to back-arc. Geosci. Front. 4, 377-388.

Armijo, R., Lacassin, R., Coudurier-Curveur, A., Carrizo, D., 2015. Coupled tectonic evolution of Andean orogeny and global climate. Earth Sci. Rev. 143, 1-35. https:// doi.org/10.1016/j.earscirev.2015.01.005.

Atkinson, B.K., 1989. Introduction to fracture mechanics and its geophysical applications. In: Atkinson, B.K. (Ed.), Fracture Mechanics of Rock. Academic Press Limited, pp. 1-26. https://doi.org/10.1016/B978-0-12-066266-1.50006-5.

Bangs, N.L., Cande, S.C., 1997. Episodic development of a convergent margin inferred from structures and processes along the Southern Chile margin. Tectonics 16, 489-503.

Barberón, V., Sue, C., Ghiglione, M., Ronda, G., Aragón, E., 2018. Late Cenozoic brittle deformation in the Southern Patagonian Andes: record of plate coupling/decoupling during variable subduction? Terra Nova 30, 296-309. https://doi.org/10.1111/ ter.12339.

Barberón, V., Ronda, G., Aramendía, I., Suárez, R.J., Ramos, M.E., Naipauer, M., Sue, C., Ghiglione, M.C., 2019. Tectonic evolution of the northern Austral-Magallanes basin in the Southern Patagonian Andes from provenance analysis. J. South Am. Earth Sci. 95, 102234 https://doi.org/10.1016/j.jsames.2019.102234.

Bassett, D., Watts, A.B., 2015a. Gravity anomalies, crustal structure, and seismicity at subduction zones: 1. Seafloor roughness and subducting relief. Geochem. Geophys. Geosystems 16, 1508-1540.

Bassett, D., Watts, A.B., 2015b. Gravity anomalies, crustal structure, and seismicity at subduction zones: 2 . Interrelationships between fore-arc structure and seismogenic behavior. Geochem. Geophys. Geosystems 16, 1541-1576.

Becerra, J., Contreras-Reyes, E., Arriagada, C., 2013. Seismic structure and tectonics of the Southern Arauco Basin, south-central Chile ( $\sim 38^{\circ}$ S). Tectonophysics 592, 53-66.

Bechis, F., Cristallini, E., 2006. Inflexiones en estructuras del sector norte de la faja plegada y corrida de Ñirihuau, provincia de Río Negro. Rev. Asoc. Geol. Argent. 6, 18-25.

Becker, J.J., Sandwell, D.T., Smith, W.H.F., Braud, J., Binder, B., Depner, J., Fabre, D., Factor, J., Ingalls, S., Kim, S.-H., Ladner, R., Marks, K., Nelson, S., Pharaoh, A., Trimmer, R., Von Rosenberg, R., Wallace, G., Weatherall, P., 2009. Global bathymetry and elevation data at 30 arc seconds resolution: SRTM30_PLUS. Mar. Geod. 32 (4), 355-371. https://doi.org/10.1080/01490410903297766.

Bilmes, A., D’Elia, L., Franzese, J.R., Veiga, G.D., Hernández, M., 2013. Miocene block uplift and basin formation in the Patagonian foreland: the Gastre Basin, Argentina. Tectonophysics 601, 98-111.

Braitenberg, C., Mariani, P., Ebbing, J., Sprlak, M., 2011. The enigmatic Chad lineament revisited with global gravity and gravity-gradient fields. In: Van Hinsbergen, D.J.J., Buiter, S.J.H., Torsvik, T.H., Gaina, C., Webb, S.J. (Eds.), The Formation and Evolution of Africa: A Synopsis of 3.8 Ga of Earth History, 357. Geological Society, London, Special Publications, pp. 329-341.

Bray, C.J., Karig, D.E., 1985. Porosity of sediments in accretionary prisms and some implications for dewatering processes. J. Geophys. Res. Solid Earth 90, 768-778.

Breitsprecher, K., Thorkelson, D.J., 2009. Neogene kinematic history of Nazca-Antarctic-Phoenix slab windows beneath Patagonia and the Antarctic Peninsula. Tectonophysics 464, 10-20.

Bruinsma, S.L., Förste, C., Abrikosov, O., Marty, J.-C., Rio, M-H., Mulet, S., Bonvalot, S., 2013. The new ESA satellite-only gravity field model via the direct approach. Geophys. Res. Lett. 40, 3607-3612.

Cande, S.C., Leslie, R.B., 1986. Late cenozoic tectonics of the Southern Chile trench. J. Geophys. Res. 91, 471-496.

Canny, J., 1986. A computational approach to edge detection. IEEE Transactions on Pattern Analysis and Machine Intelligence PAMI-8 679-698. https://doi.org/ 10.1109/TPAMI.1986.4767851.

Carena, S., 2011. Subducting-plate topography and nucleation of great and giant earthquakes along the South American trench. Seismol. Res. Lett. 82, 629-637.

Castro, A., Moreno-Ventas, I., Fernández, C., Vujovich, G., Gallastegui, G., Heredia, N., Martino, R.D., Becchio, R., Corretgé, L.G., Díaz-Alvarado, J., Such, P., GarcíaArias, M., Liu, D.-Y., 2011. Petrology and SHRIMP U-Pb zircon geochronology of Cordilleran granitoids of the Bariloche area, Argentina. J. South Am. Earth Sci. 32, 508-530.

Cembrano, J., Lara, L., 2009. The link between volcanism and tectonics in the southern volcanic zone of the Chilean Andes: a review. Tectonophysics 471, 96-113.

Cembrano, J., Hervé, F., Lavenu, A., 1996. The Liquiñe Ofqui fault zone: a long-lived intra-arc fault system in southern Chile. Tectonophysics 259, 55-66.

Champagnac, J.D., Molnar, P., Anderson, R.S., Sue, C., Delacou, B., 2007. Quaternary erosion-induced isostatic rebound in the western Alps. Geology 35, 195-198.

Cloetingh, S., Ziegler, P., Beekman, F., Andriessen, P., Matenco, L., Bada, G., GarciaCastellanos, D., Hardebol, N., Dezes, P., Sokoutis, D., 2005. Lithospheric memory, state of stress and rheology: neotectonic controls on Europe's intraplate continental topography. Quat. Sci. Rev. 24, 241-304.

Cobbold, P., Rossello, E., 2003. Aptian to recent compressional deformation, foothills of the Neuquén Basin, Argentina. Mar. Pet. Geol. 20, 429-443.

Contreras-Reyes, E., Carrizo, D., 2011. Control of high oceanic features and subduction channel on earthquake ruptures along the Chile-Peru subduction zone. Phys. Earth Planet. Inter. 186, 49-58.

Contreras-Reyes, E., Grevemeyer, I., Flueh, E.R., Reichert, C., 2008. Upper lithospheric structure of the subduction zone offshore of southern Arauco peninsula, Chile, at $\sim 38^{\circ}$ S. J. Geophys. Res. Solid Earth 113, 1-19.

Contreras-Reyes, E., Jara, J., Maksymowicz, A., Weinrebe, W., 2013. Sediment loading at the southern Chilean trench and its tectonic implications. J. Geodyn. 66, 134-145. 
Cross, T.A., Pilger, R.H., 1982. Controls of subduction geometry, location of magmatic arcs, and tectonics of arc and back-arc regions. Geol. Soc. Am. Bull. 93, 545.

Cubas, N., Avouac, J.-P., Souloumiac, P., Leroy, Y., 2013. Megathrust friction determined from mechanical analysis of the forearc in the Maule earthquake area. Earth Planet. Sci. Lett. 381, 92-103.

Das, S., Watts, A.B., 2009. Effect of subducting seafloor topography on the rupture characteristics of great subduction zone earthquakes. In: Lallemand, S., Funiciello, F. (Eds.), Subduction Zone Geodynamics. Springer-Verlag Berlin, Heidelberg, pp. 103-118.

DeMets, C., Gordon, R.G., Argus, D.F., 2010. Geologically current plate motions. Geophys. J. Int. 181, 1-80.

Dzierma, Y., Rabbel, W., Thorwart, M., Koulakov, I., Wehrmann, H., Hoernle, K. Comte, D., 2012a. Seismic velocity structure of the slab and continental plate in the region of the 1960 Valdivia (Chile) slip maximum — insights into fluid release and plate coupling. Earth Planet. Sci. Lett. 331-332, 164-176.

Dzierma, Y., Thorwart, M., Rabbel, W., 2012b. Moho topography and subducting oceanic slab of the Chilean continental margin in the maximum slip segment of the $1960 \mathrm{Mw}$ 9.5 Valdivia (Chile) earthquake from P-receiver functions. Tectonophysics 530-531, 180-192.

Eagles, G., Scott, B.G.C., 2014. Plate convergence west of Patagonia and the Antarctic Peninsula since 61Ma. Glob. Planet. Change 123, 189-198.

Eagles, G., Gohl, K., Larter, R.D., 2009. Animated tectonic reconstruction of the Southern Pacific and alkaline volcanism at its convergent margins since Eocene times. Tectonophysics 464, 21-29.

Echaurren, A., Folguera, A., Gianni, G., Orts, D., Tassara, A., Encinas, A., Giménez, M., Valencia, V., 2016. Tectonic evolution of the North Patagonian Andes ( $\left.41^{\circ}-44^{\circ} \mathrm{S}\right)$ through recognition of syntectonic strata. Tectonophysics 677, 99-114.

Encinas, A., Finger, K.L., Buatois, L.A., Peterson, D.E., 2012. Major forearc subsidence and deep-marine Miocene sedimentation in the present Coastal Cordillera and longitudinal depression of south-central Chile ( $\left.38^{\circ} 30^{\prime} \mathrm{S}-41^{\circ} 45^{\prime} \mathrm{S}\right)$. Geol. Soc. Am. Bull. 124, 1262-1277.

Encinas, A., Folguera, A., Oliveros, V., De Girolamo Del Mauro, L., Tapia, F., Riffo, R., Hervé, F., Finger, K.L., Valencia, V.A., Gianni, G., Álvarez, O., 2016. Late Oligocene-early Miocene submarine volcanism and deep-marine sedimentation in an extensional basin of southern Chile: implications for the tectonic development of the North Patagonian Andes. Geol. Soc. Am. Bull. 128, 807-823.

Flament, N., Gurnis, M., Müller, R.D., Bower, D.J., Husson, L., 2015. Influence of subduction history on South American topography. Earth Planet. Sci. Lett. 430, 9-18.

Folguera, A., Ramos, V.A., 2002. Partición de la deformación durante el Neógeno en los Andes Patagónicos Septentrionales $\left(37^{\circ}-46^{\circ} \mathrm{S}\right)$. Revista de la Sociedad Geológica de España 15, 81-93.

Folguera, A., Ramos, V.A., 2009. Collision of the Mocha fracture zone and a <4 Ma old wave of orogenic uplift in the Andes (36-38 S). Lithosphere 1, 364-369.

Folguera, A., Ramos, V.A., 2011. Repeated eastward shifts of arc magmatism in the Southern Andes: a revision to the long-term pattern of Andean uplift and magmatism. J. South Am. Earth Sci. 32, 531-546.

Folguera, A., Rojas Vera, E., Bottesi, G., Zamora Valcarce, G., Ramos, V.A., 2010. The Loncopué Trough: a Cenozoic basin produced by extension in the southern Central Andes. J. Geodyn. 49, 287-295.

Folguera, A., Alasonati Tašárová, Z., Götze, H.-J., Rojas Vera, E., Giménez, M., Ramos, V. A., 2012. Retroarc extension in the last $6 \mathrm{Ma}$ in the South-Central Andes ( $36^{\circ} \mathrm{S}-40^{\circ} \mathrm{S}$ ) evaluated through a 3-D gravity modelling. J. South Am. Earth Sci. 40, 23-37.

Folguera, A., Zárate, M., Tedesco, A., Dávila, F., Ramos, V.A., 2015. Evolution of the Neogene Andean foreland basins of the Southern Pampas and Northern Patagonia $\left(34^{\circ}-41^{\circ} \mathrm{S}\right)$, Argentina. J. South Am. Earth Sci. 64, 452-466.

Garcia-Morabito, E., Götze, H.-J., Ramos, V.A., 2011. Tertiary tectonics of the Patagonian Andes retro-arc area between $38^{\circ} 15^{\prime}$ and $40^{\circ} \mathrm{S}$ latitude. Tectonophysics 499, 1-21.

Ghiglione, M., Suarez, F., Ambrosio, A., Da Poian, G., Cristallini, E.O., Pizzio, M.F., Reinoso, R.M., 2009. Structure and evolution of the Austral Basin fold-thrust belt, southern Patagonian Andes. Revista de la Asociación Geológica Argentina 65, 215-226.

Giacosa, R.E., Heredia, N., 2004. Structure of the North Patagonian thick-skinned foldand-thrust belt, southern central Andes, Argentina ( $\left.41^{\circ}-42^{\circ} \mathrm{S}\right)$. J. South Am. Earth Sci. 18, 61-72.

Giacosa, R., Márquez, M., 1999. Jurásico y Cretácico de la Cordillera Patagónica septentrional y precordillera Patagónica. In: Caminos, R. (Ed.), Geología Argentina. Instituto de Geología y Recursos Minerales, Anales 29, Servicio Geológico Minero Argentino, Buenos Aires, pp. 444-459.

Giacosa, R., Zubia, M., Sánchez, M., Allard, J., 2010. Meso-Cenozoic tectonics of the southern Patagonian foreland: structural evolution and implications for Au-Ag veins in the eastern Deseado Region (Santa Cruz, Argentina). J. South Am. Earth Sci. 30, 134-150.

Gianni, G., Navarrete, C., Orts, D., Tobal, J., Folguera, A., Giménez, M., 2015. Patagonian broken foreland and related synorogenic rifting: the origin of the Chubut Group Basin. Tectonophysics 649, 81-99.

Global Volcanism Program, 2013. In: Venzke, E. (Ed.), Volcanoes of the World, v. 4.4.1. Smithsonian Institution. https://doi.org/10.5479/si.GVP.VOTW4-2013. Downloaded 16 Dec 2015.

Glodny, J., Echtler, H., Figueroa, O., Franz, G., Gräfe, K., Kemnitz, H., Kramer, W., Krawczyk, C., Lohrmann, J., Lucassen, F., Melnick, D., Rosenau, M., Seifert, W., 2006. Long-term geological evolution and mass flow balance of the South-Central Andes. In: Oncken, O., Chong, G., Franz, G., Giese, P., Götze, H.-J., Ramos, V., Strecker, M., Wigger, P. (Eds.), The Andes-Active Subduction Orogeny. Frontiers in Earth Sciences, vol. 1. Springer-Verlag, Berlin, Heidelberg, New York, pp. 401-442.
Guillaume, B., Martinod, J., Husson, L., Roddaz, M., Riquelme, R., 2009. Neogene uplift of central eastern Patagonia: dynamic response to active spreading ridge subduction? Tectonics 28. TC2009.

Gutscher, M.A., Malavieille, J., Lallemand, S., Collot, J.Y., 1999. Tectonic segmentation of the north andean margin: impact of the Carnegie Ridge collision. Earth Planet. Sci. Lett. 168, 255-270. https://doi.org/10.1016/S0012-821X(99)00060-6.

Gutscher, M.A., Spakman, W., Bijwaard, H., Engdahl, E.R., 2000. Geodynamics of flat subduction: seismicity and tomographic constraints from the Andean margin. Tectonics 19, 814-833. https://doi.org/10.1029/1999TC001152.

Hackney, R., Echtler, H.P., Franz, G., Götze, H.-J., Lucassen, F., Marchenko, D., Melnick, D., Meyer, U., Schmidt, S., Tasárová, Z., Tassara, A., Wienecke, S., et al., 2006. The segmented overriding plate and coupling at the south-central Chilean margin (36-42 S). In: Oncken (Ed.), The Andes-Active Subduction Orogeny. Frontiers in Earth Sciences, vol. 1. Springer-Verlag, Berlin, Heidelberg, New York, pp. 355-374.

Herman, F., Brandon, M., 2015. Mid-latitude glacial erosion hotspot related to equatorial shifts in southern Westerlies. Geology 43, 987-990.

Herman, F., Seward, D., Valla, P.G., Carter, A., Kohn, B., Willett, S.D., Ehlers, T.A., 2013. Worldwide acceleration of mountain erosion under a cooling climate. Nature 504, 423-426.

Hernandez-Moreno, C., Speranza, F., Di Chiara, A., 2014. Understanding kinematics of intra-arc transcurrent deformation: paleomagnetic evidence from the Liqui??e-Ofqui fault zone (Chile, 38-41S). Tectonics 33, 1964-1988.

Hervé, F., 1994. The Southern Andes between $39^{\circ}$ and $44^{\circ} \mathrm{S}$ latitude: the geological signature of a transpressive tectonic regime related to a magmatic arc. In: Reutter, K.J., Scheuber, E., Wigger, P.J. (Eds.), Tectonics of the Southern Central Andes. Springer, Berlin, pp. 243-248.

Hervé, F., Pankhurst, R.J., Drake, R., Beck, M.E., Mpodozis, C., 1993. Granite generation and rapid unroofing related to strike-slip faulting, Aysén, Chile. Earth Planet. Sci. Lett. 120, 375-386.

Hervé, F., Faundez, V., Calderón, M., Massonne, H., Willner, A.P., 2007. Basement complexes. In: Moreno, T., Gibbons, W. (Eds.), The Geology of Chile. Geological Society, London, pp. 5-19.

Hervé, F., Calderón, M., Fanning, C.M., Pankhurst, R.J., Godoy, E., 2013. Provenance variations in the Late Paleozoic accretionary complex of central Chile as indicated by detrital zircons. Gondwana Res. 23, 1122-1135.

Heuret, A., Conrad, C.P., Funiciello, F., Lallemand, S., Sandri, L., 2012. Relation between subduction megathrust earthquakes, trench sediment thickness and upper plate strain. Geophys. Res. Lett. 39, 1-6.

Homovc, J.F., Conforto, G.A., Lafourcade, P.A., y Chelotti, L.A., 1995. Fold belt in the San Jorge Basin, Argentine: an example of tectonic inversion. In: Buchanan, J.G., Buchanan, P.G. (Eds.), Basin Inversion, 88. Geological Society, Special Publication, pp. 235-248.

Huyghe, D., Nivière, B., Bonnel, C., 2015. Geomorphologic evidence for Plio-Quaternary shortening in the southern Neuquén basin ( $40^{\circ} \mathrm{S}$, Argentina). Terra Nova 27, 426-432.

Hyndman, R.D., Currie, C.A., Mazzotti, S.P., 2005. Subduction zone backarcs, mobile belts, and orogenic heat. GSA Today 15, 4-10.

Iaffaldano, G., Bunge, H., 2015. Rapid plate motion variations through geological time: observations serving geodynamic interpretation. Annu. Rev. Earth Planet. Sci. 43, $571-592$.

Isacks, B.L., 1988. Uplift of the Central Andean Plateau and bending of the bolivian orocline. J. Geophys. Res. 93, 3211-3231.

Jacques, J., 2003. A tectonostratigraphic synthesis of the Sub-Andean basins: implications for the geotectonic segmentation of the Andean Belt. J. Geol. Soc. 160, 687-701.

Jarvis, A., Reuter, H.I., Nelson, A., Guevara, E., 2008. Hole-filled SRTM for the Globe Version 4. available from the CGIAR-CSI SRTM 90m Database. http://srtm.csi.cgiar. org).

Jordan, T.A., Isacks, B.L., Allmendinger, R.W., Brewer, J.A., Ramos, V.A., Clifford, J.A., 1983. Andean tectonics related to geometry of subducted Nazca plate. Geol. Soc. Am. Bull. 94, 341-361. https://doi.org/10.1130/0016-7606(1983)94<341.

Kay, S.M., Ramos, V.A., Mpodozis, C., Sruoga, P., 1989. Late Paleozoic to Jurassic silicic magmatism at the Gondwana margin, anology to the Middle Proterozoic in North America? Geology 17, 324-328.

Kay, S., Burns, W., Copeland, P., Mancilla, O., 2006. Upper cretaceous to holocene magmatism and evidence for transient miocene shallowing of the Andean subduction zone under the northern Neuquén Basin. In: Kay, S.M., Ramos, V.A. (Eds.), Evolution of an Andean Margin: A Tectonic and Magmatic View from the Andes to the Neuquén Basin (35 -39 S Lat), 407. Geological Society of America Special Paper, pp. 19-60.

Kay, S.M., Ardolino, A.A., Gorring, M.L., Ramos, V.A., 2007. The somuncura large igneous province in Patagonia: interaction of a transient mantle thermal anomaly with a subducting slab. J. Petrol. 48, 43-77.

Keppie, D.F., Currie, C.A., Warren, C., 2009. Subduction erosion modes: comparing finite element numerical models with the geological record. Earth Planet. Sci. Lett. 287, $241-254$.

Kim, Y.-S., Peacock, D.C., Sanderson, D.J., 2004. Fault damage zones. J. Struct. Geol. 26, 503-517.

Kley, J., Monaldi, C.R., Salfity, J.A., 1999. Along-strike segmentation of the Andean foreland: causes and consequences. Tectonophysics 301, 75-94.

Kollenz, S., Glasmacher, U.A., Rossello, E.A., Stockli, D.F., Schad, S., Pereyra, R.E., 2016. Thermochronological constraints on the Cambrian to recent geological evolution of the Argentina passive continental margin. Tectonophysics. https://doi.org/10.1016/ j.tecto.2016.11.019 in press. 
Kopp, H., 2013. Invited review paper: the control of subduction zone structural complexity and geometry on margin segmentation and seismicity. Tectonophysics 589, 1-16.

Kulander, B.R., Barton, C.C., Dean, S.L., 1979. The Application of Fractography to core and Outcrop Fracture Investigations, Vol. 174. U.S. Dept. of Energy, METC/SP-79/3; National Technical Information Service, U.S. Dept. of Commerce, Springfield, VA, p. 22161. Rep.

Lagabrielle, Y., Suárez, M., Rossello, E.A., Hérail, G., Martinod, J., Régnier, M., de la Cruz, R., 2004. Neogene to quaternary tectonic evolution of the Patagonian Andes at the latitude of the Chile triple junction. Tectonophysics 385, 211-241.

Lagabrielle, Y., Suárez, M., Malavieille, J., Morata, D., Espinoza, F., Maury, R.C., Scalabrino, B., Barbero, L., de la Cruz, R., Rossello, E., Bellon, H., 2007. Pliocene extensional tectonics in the Eastern Central Patagonian Cordillera: geochronological constraints and new field evidence. Terra Nova 19, 413-424. https://doi.org/ 10.1111/j.1365-3121.2007.00766.x.

Lamb, S., Davis, P., 2003. Cenozoic climate change as a possible cause for the rise of the Andes. Nature 425, 792-797.

Lange, D., Ruiz, J., Carrasco, S., Manríquez, P., 2018. The Chiloé Mw 7.6 earthquake of 2016 December 25 in Southern Chile and its relation to the Mw 9.51960 Valdivia earthquake. Geophys. J. Int. 213, 210-221. https://doi.org/10.1093/gji/ggx514.

Laursen, J., Scholl, D.W., von Huene, R., 2002. Neotectonic deformation of the central Chile margin: deepwater forearc basin formation in response to hot spot ridge and seamount subduction. Tectonics 21, 1038.

Lavenu, A., Cembrano, J., 1999. Compressional- and transpressional-stress pattern for Pliocene and Quaternary brittle deformation in fore arc and intra-arc zones (Andes of Central and Southern Chile). J. Struct. Geol. 21, 1669-1691.

Lay, T., Kanamori, H., Ammon, C.J., Koper, K.D., Hutko, A.R., Ye, L., Yue, H., Rushing, T. M., 2012. Depth-varying rupture properties of subduction zone megathrust faults. J. Geophys. Res. Solid Earth 117, 1-21.

Li, X., 2001. Vertical resolution: gravity versus vertical gravity gradient. Lead. Edge 20, 901-904.

Lithgow-Bertelloni, C., Gurnis, M., 1997. Cenozoic subsidence and uplift of continents from time-varying dynamic topography. Geology 25, 735-738.

Loveless, J.P., Allmendinger, R.W., Pritchard, M.E., Garroway, J.L., Gonzalez, G., 2009. Surface cracks record long-term seismic segmentation of the Andean margin. Geology 37, 23-26.

Loveless, J.P., Pritchard, M.E., Kukowski, N., 2010. Testing mechanisms of subduction zone segmentation and seismogenesis with slip distributions from recent Andean earthquakes. Tectonophysics 495, 15-33.

Maksymowicz, A., 2015. The geometry of the Chilean continental wedge: tectonic segmentation of subduction processes off Chile. Tectonophysics 659, 183-196.

Maksymowicz, A., Contreras-Reyes, E., Grevemeyer, I., Flueh, E.R., 2012. Structure and geodynamics of the post-collision zone between the Nazca-Antarctic spreading center and South America. Earth Planet. Sci. Lett. 345-348, 27-37.

Manea, V.C., Leeman, W.P., Gerya, T., Manea, M., Zhu, G., 2014. Subduction of fracture zones controls mantle melting and geochemical signature above slabs. Nat. Commun. 5, 5095. https://doi.org/10.1038/ncomms6095.

Martínez, O.A., Kutschker, A., 2011. The "Rodados Patagónicos" (Patagonian shingle formation) of eastern Patagonia: environmental conditions of gravel sedimentation. Biol. J. Linn. Soc. 103, 336-345.

Martinod, J., Regard, V., Letourmy, Y., Henry, H., Hassani, R., Baratchart, S., Carretier, S., 2016. How do subduction processes contribute to forearc Andean uplift? Insights from numerical models. J. Geodyn. 96, 6-18.

Martinod, J., Gérault, M., Husson, L., Regard, V., 2020. Earth-science reviews widening of the Andes: an interplay between subduction dynamics and crustal wedge tectonics. Earth. Rev. 204, 103170 https://doi.org/10.1016/j. earscirev.2020.103170.

Matthews, K.J., Müller, R.D., Wessel, P., Whittaker, J.M., 2011. The tectonic fabric of the ocean basins. J. Geophys. Res. 116, B12109.

Matthews, K.J., Seton, M., Müller, R.D., 2012. A global-scale plate reorganization event at 105-100Ma. Earth Planet. Sci. Lett. 355-356, 283-298.

Maus, E., 2009. EMAG2: Earth Magnetic Anomaly Grid (2-arc-minute resolution). National Geophysical Data Center, NOAA. Model. https://doi.org/10.7289/ V5MW2F2P.

Melnick, D., 2016. Rise of the central Andean coast by earthquakes straddling the Moho. Nat. Geosci. 9, 401-407.

Melnick, D., Bookhagen, B., Strecker, M.R., Echtler, H.P., 2009. Segmentation of megathrust rupture zones from fore-arc deformation patterns over hundreds to millions of years, Arauco peninsula, Chile. J. Geophys. Res. 114, 1-23.

Métois, M., Vigny, C., Socquet, A., 2016. Interseismic coupling, megathrust earthquakes and seismic swarms along the chilean subduction zone $\left(38^{\circ}-18^{\circ} \mathrm{S}\right)$. Pure Appl. Geophys. 173, 1431-1449.

Molnar, P., Atwater, T., 1978. Interarc spreading and Cordilleran tectonics as alternates related to the age of subducted oceanic lithosphere. Earth Planet. Sci. Lett. 41 , 330-340.

Montgomery, D.R., Balco, G., Willett, S.D., 2001. Climate, tectonics, and the morphology of the Andes. Geology 29, 579.

Moreno, M.S., Bolte, J., Klotz, J., Melnick, D., 2009. Impact of megathrust geometry on inversion of coseismic slip from geodetic data: application to the 1960 Chile earthquake. Geophys. Res. Lett. 36, 1-5.

Moreno, M., Melnick, D., Rosenau, M., Bolte, J., Klotz, J., Echtler, H., Baez, J., Bataille, K., Chen, J., Bevis, M., Hase, H., Oncken, O., 2011. Heterogeneous plate locking in the South - central Chile subduction zone : building up the next great earthquake. Earth Planet. Sci. Lett. 305, 413-424.

Moreno, M., Melnick, D., Rosenau, M., Baez, J., Klotz, J., Oncken, O., Tassara, A., Chen, J., Bataille, K., Bevis, M., Socquet, A., Bolte, J., Vigny, C., Brooks, B., Ryder, I,
Grund, V., Smalley, B., Carrizo, D., Bartsch, M., Hase, H., 2012. Toward understanding tectonic control on the Mw 8.8 2010 Maule Chile earthquake. Earth Planet. Sci. Lett. 321-322, 152-165.

Moreno, M., Haberland, C., Oncken, O., Rietbrock, A., Angiboust, S., Heidbach, O., 2014. Locking of the Chile subduction zone controlled by fluid pressure before the 2010 earthquake. Nat. Geosci. 7, 292-296.

Mosquera, A., Ramos, V.A., 2006. Intraplate deformation in the Neuquén embayment. In: Kay, S.M., Ramos, V.A. (Eds.), Evolution of an Andean Margin: A Tectonic and Magmatic View from the Andes to the Neuquén Basin (35-39 ${ }^{\circ} \mathrm{S}$ Lat), 407. Geological Society of America Special Paper, pp. 97-125.

Müller, R.D., Landgrebe, T.C.W., 2012. The link between great earthquakes and the subduction of oceanic fracture zones. Solid Earth 3, 447-465. https://doi.org/ 10.5194/se-3-447-2012.

Müller, R.D., Sdrolias, M., Gaina, C., Roest, W.R., 2008. Age, spreading rates, and spreading asymmetry of the world's ocean crust. Geochem. Geophys. Geosystems 9, $1-19$.

Müller, R.D., Seton, M., Zahirovic, S., Williams, S.E., Matthews, K.J., Wright, N.M., Shephard, G.E., Maloney, K.T., Barnett-Moore, N., Hosseinpour, M., Bower, D.J., Cannon, J., 2016. Ocean basin evolution and global-scale plate reorganization events since pangea breakup. Annu. Rev. Earth Planet. Sci. 44, 107-138. https://doi.org/ 10.1146/annurev-earth-060115-012211.

Muñoz, J., Troncoso, R., Duhart, P., Crignola, P., Farmer, L., Stern, C.R., 2000. The relation of the mid-Tertiary coastal magmatic belt in south-central Chile to the late Oligocene increase in plate convergence rate. Revista Geológica de Chile 27, 177-203.

Nivière, B., Messager, G., Carretier, S., Lacan, P., 2013. Geomorphic expression of the southern Central Andes forebulge ( $37^{\circ} \mathrm{S}$, Argentina). Terra Nova 25, 361-367.

Noda, A., 2016. Forearc basins: types, geometries, and relationships to subduction zone dynamics. Geol. Soc. Am. Bull. 128, 879-895.

Orts, D.L., Folguera, A., Encinas, A., Ramos, M., Tobal, J., Ramos, V.A., 2012. Tectonic development of the North Patagonian Andes and their related Miocene foreland basin $\left(41^{\circ} 30^{\prime}-43^{\circ} \mathrm{S}\right)$. Tectonics $31,1-24$.

Orts, D.L., Folguera, A., Giménez, M., Ruiz, F., Rojas Vera, E.A., Lince Klinger, F., 2015. Cenozoic building and deformational processes in the North Patagonian Andes. J. Geodyn. 86, 26-41.

Pankhurst, R.J., Rapela, C.R., 1995. Production of Jurassic rhyolite by anatexis of the lower crust of Patagonia. Earth Planet. Sci. Lett. 134, 23-36.

Pankhurst, R.J., Weaver, S.D., Hervé, F., Larrondo, P., 1999. Mesozoic-cenozoic evolution of the north patagonian batholith in Aysen, southern Chile. J. Geol. Soc. $156,673-694$.

Pankhurst, R.J., Rapela, C.W., Fanning, C.M., Márquez, M., 2006. Gondwanide continental collision and the origin of Patagonia. Earth. Rev. 76, 235-257.

Pavlis, N.K., Holmes, Sa., Kenyon, S.C., Factor, J.K., 2012. The development and evaluation of the Earth Gravitational Model 2008 (EGM2008). J. Geophys. Res. 117, B04406.

Pérez-Gussinyé, M., Lowry, A.R., Watts, A.B., 2007. Effective elastic thickness of South America and its implications for intracontinental deformation. Geochem. Geophys. Geosystems 8, Q05009. https://doi.org/10.1029/2006GC001511.

Quinteros, J., Sobolev, S.V., 2013. Why has the Nazca plate slowed since the Neogene? Geology 41, 31-34.

Ramos, V.A., 2008. Patagonia: a paleozoic continent adrift? J. South Am. Earth Sci. 26, 235-251.

Ramos, V.A., 2009. Anatomy and global context of the Andes: Main geologic features and the Andean orogenic cycle. In: Kay, S.M., Ramos, V.A., Dickinson, W.R. (Eds.), Backbone of the Americas: Shallow Subduction, Plateau Uplift, and Ridge and Terrane Collision. Geological Society of America, pp. 31-65. https://doi.org/ 10.1130/2009.1204(02).

Ramos, M.E., Folguera, A., Fennell, L., Giménez, M., Litvak, V.D., Dzierma, Y., Ramos, V. A., 2014. Tectonic evolution of the North Patagonian Andes from field and gravity data (39-40 S). J. South Am. Earth Sci. 51, 59-75.

Ranero, C., von Huene, R., Weinrebe, W., Reichert, C., et al., 2006. Tectonic processes along the Chile convergent margin. In: Oncken, O., Chong, G. (Eds.), The Andes-Active Subduction Orogeny. Frontiers in Earth Sciences, vol. 1. SpringerVerlag, Berlin, Heidelberg, New York, pp. 91-121.

Rapela, C.W., Pankhurst, R.J., Fanning, C.M., Herve, F., 2005. Pacific subduction coeval with the Karoo mantle plume: the early Jurasssic Subcordilleran belt of northwestern Patagonia. In: Vaughan, A.P.M., Leat, P.T., Pankhurst, R.J. (Eds.), Terrane Processes at the Margins of Gondwana, 246. Geological Society, London, Special Publications, pp. 217-239.

Rojas-Vera, E.A., Folguera, A., Valcarce, G.Z., Giménez, M., Ruiz, F., Martínez, P., Bottesi, G., Ramos, V.A., 2010. Neogene to Quaternary extensional reactivation of a fold and thrust belt: the Agrio belt in the Southern Central Andes and its relation to the Loncopué trough $\left(38^{\circ}-39^{\circ} \mathrm{S}\right)$. Tectonophysics 492, 279-294.

Rojas-Vera, E.A., Folguera, A., Zamora Valcarce, G., Bottesi, G., Ramos, V.A., 2014. Structure and development of the Andean system between $36^{\circ}$ and $39^{\circ} \mathrm{S}$. J. Geodyn. 73, 34-52.

Rosenbaum, G., Mo, W., 2011. Tectonic and magmatic responses to the subduction of high bathymetric relief. Gondwana Res. 19, 571-582.

Rotman, H.M.M., Spinelli, G.A., 2014. Remarkably consistent thermal state of the south central Chile subduction zone from $36^{\circ} \mathrm{S}$ to $45^{\circ} \mathrm{S}$. J. Geophys. Res. Solid Earth 119, 3503-3516.

Russo, R.M., VanDecar, J.C., Comte, D., Mocanu, V.I., Gallego, A., Murdie, R.E., 2010. Subduction of the Chile Ridge: upper mantle structure and flow. GSA Today 20, $4-10$.

Sagripanti, L., Rojas Vera, E.A., Gianni, G.M., Folguera, A., Harvey, J.E., Farías, M., Ramos, V.A., 2015. Neotectonic reactivation of the western section of the Malargüe 
fold and thrust belt (Tromen volcanic plateau, Southern Central Andes). Geomorphology 232, 164-181.

Sandwell, D.T., Smith, W.H.F., 1997. Marine gravity anomaly from Geosat and ERS 1 satellite altimetry. J. Geophys. Res. Solid Earth 102, 10039-10054.

Savignano, E., Mazzoli, S., Arce, M., Franchini, M., Gautheron, C., Paolini, M., Zattin, M. 2016. (Un)Coupled thrust belt-foreland deformation in the northern Patagonian Andes: new insights from the Esquel-Gastre sector $\left(41^{\circ} 30^{\prime}-43^{\circ} \mathrm{S}\right)$. Tectonics 309732108, 1-21.

Scalabrino, B., Lagabrielle, Y., de la Rupelle, A., Malavieille, J., Polvé, M., Espinoza, F., Morata, D., Suarez, M., 2009. Subduction of an active spreading Ridge beneath Southern South America: a review of the Cenozoic geological records from the Andean foreland, Central Patagonia ( $\left.46-47^{\circ} \mathrm{S}\right)$. In: Lallemand, S., Funiciello, F. (Eds.), Subduction Zone Geodynamics. Frontiers in Earth Sciences. Springer-Verlag, Heidelberg, pp. 227-246. https://doi.org/10.1007/978-3-540-87974-9_12.

Schellart, W.P., 2008. Overriding plate shortening and extension above subduction zones: A parametric study to explain formation of the Andes Mountains. GSA Bulletin 120 (11/12), 1441-1454. https://doi.org/10.1130/B26360.1.

Sdrolias, M., Müller, R.D., 2006. Controls on back-arc basin formation. Geochem. Geophys. Geosystems 7, Q04016. https://doi.org/10.1029/2005GC001090.

SEGEMAR, 1999. Mapa Geológico de la República Argentina. Escala 1:2.500.000, Servicio Geológico Minero Argentino.

SERNAGEOMIN, 2003. Mapa Geológico de Chile: versión digital. Servicio Nacional de Geología y Minería, Publicación Geológica Digital, no. 4. (CD-ROM, versión1.0, 2003, Santiago de Chile.

Seton, M., Müller, R.D., Zahirovic, S., Gaina, C., Torsvik, T., Shephard, G., Talsma, A., Gurnis, M., Turner, M., Maus, S., Chandler, M., 2012. Earth-science reviews global continental and ocean basin reconstructions since 200 Ma. Earth Sci. Rev. 113, 212-270.

Shevyrev, S.L., 2018. LEFA. Lineament extraction and fracture analysis software. Official web site. URL: http://lefa.geologov.net.

Shevyrev, S., 2019. Neotectonics, remote sensing and erosion cut of ore-controlling structures of the Mnogovershinnoe gold-silver deposit (Khabarovsk Krai, Russian Far East). Ore Geol. Rev. 108, 8-22. https://doi.org/10.1016/j.oregeorev.2018.11.016.

Small, E.E., Anderson, R.S., 1998. Pleistocene relief production in Laramide mountain ranges, Western United States. Geology 26, 123-126.

Somoza, R., 1998. Updated Nazca (Farallon)—South America relative motions during the last 40 my: implications for mountain building in the central Andean region. J. South Am. Earth Sci. 11, 211-215.

Somoza, R., Ghidella, M.E., 2005. Convergencia en el margen occidental de América de sur durante el Cenozoico: subducción de las placas de Nazca, Farallón y Aluk. Revista de la Asociación Geológica Argentina 60, 797-809.

Song, T.-R.A., 2003. Large trench-parallel gravity variations predict seismogenic behavior in subduction zones. Science 301, 630-633.

Sparkes, R., Tilmann, F., Hovius, N., Hillier, J., 2010. Subducted seafloor relief stops rupture in South American great earthquakes: implications for rupture behaviour in the 2010 Maule, Chile earthquake. Earth Planet. Sci. Lett. 298, 89-94.

Spikings, R., Simpson, G., 2014. Rock uplift and exhumation of continental margins by the collision, accretion, and subduction of buoyant and topographically prominent oceanic crust. Tectonics 33, 635-655.

Strecker, M.R., Alonso, R., Bookhagen, B., Carrapa, B., Coutand, I., Hain, M.P., Hilley, G. E., Mortimer, E., Schoenbohm, L., Sobel, E.R., 2009. Does the topographic distribution of the central Andean Puna Plateau result from climatic or geodynamic processes? Geology 37, 643-646.

Tankard, A., Uliana, M.A., Welsink, H.J., Ramos, V.A., Tunik, M., Franca, A.B., Milani, E. J., de Brito Neves, B.B., Eyles, N., Skarmeta, J., Santa Ana, H., et al., 1995. Structural and tectonic controls of basin evolution in southwestern gondwana during the Phanerozoic. In: Tankard, A.J., Suarez, S.R., Weslsink, H.J. (Eds.), Petroleum Basins of South America, 62. AAPG Memoir, pp. 5-52.

Tassara, A., Yáñez, G., 2003. Relación entre el espesor elástico de la litosfera y la segmentación tectónica del margen andino $\left(15-47^{\circ} \mathrm{S}\right)$. Revista geológica de Chile 30 159-186.
Tassara, A., Swain, C., Hackney, R., Kirby, J., 2007. Elastic thickness structure of South America estimated using wavelets and satellite-derived gravity data. Earth Planet. Sci. Lett. 253, 17-36.

Thiele, S.T., Grose, L., Samsu, A., Micklethwaite, S., Vollgger, S.A., Cruden, A.R., 2017. Rapid, semi-automatic fracture and contact mapping for point clouds, images and geophysical data. Solid Earth 8, 1241-1253. https://doi.org/10.5194/se-8-12412017.

Thomson, S.N., 2002. Late Cenozoic geomorphic and tectonic evolution of the Patagonian Andes between latitudes $42^{\circ} \mathrm{S}$ and $46^{\circ} \mathrm{S}$ : an appraisal based on fissiontrack results from the transpressional intra-arc Liquiñe-Ofqui fault zone. Geol. Soc. Am. Bull. 114, 1159-1173.

Thomson, S.N., Brandon, M.T., Tomkin, J.H., Reiners, P.W., Vásquez, C., Wilson, N.J., 2010. Glaciation as a destructive and constructive control on mountain building. Nature 467, 313-317.

Tong, X., Sandwell, D., Luttrell, K., Brooks, B., Bevis, M., Shimada, M., Foster, J., Smalley, R., Parra, H., Báez Soto, J.C., Blanco, M., Kendrick, E., Genrich, J., Caccamise, D.J., 2010. The 2010 Maule, Chile earthquake: downdip rupture limit revealed by space geodesy. Geophys. Res. Lett. 37, 1-5.

Uliana, M.A., Biddle, K.T., Cerdán, J., 1989. Mesozoic extension and the formation of argentine sedimentary basins. In: Tankard, A.J., Balkwill, H.R. (Eds.), Extensional Deformation and Stratigraphy of the North Atlantic Margins, 46. American Association of Petroleum Geologists, Memoire, pp. 599-614.

Vogt, P.R., Lowrie, A., Bracey, D.R., Hey, R.N., 1976. Subduction of aseismic oceanic ridges: effects on shape, seismicity, and other characteristics of consuming plate boundaries. Special Paper - Geological Society of America, pp. 1-59. https://doi.org/ 10.1130/SPE172-p1.

Vogt, H., Vogt, T., Calmels, A.P., 2010. Influence of the post-Miocene tectonic activity on the geomorphology between Andes and Pampa Deprimida in the area of Provincia de La Pampa, Argentina. Geomorphology 121, 152-166.

Völker, D., Stipp, M., 2015. Water input and water release from the subducting Nazca Plate along southern Central Chile ( $\left.33^{\circ} \mathrm{S}-46^{\circ} \mathrm{S}\right)$. Geochem. Geophys. Geosystems 16 , 1825-1847.

Völker, D., Geersen, J., Contreras-Reyes, E., Reichert, C., 2013. Sedimentary fill of the Chile Trench (32-46 S): volumetric distribution and causal factors. J. Geol. Soc. 170, 723-736.

von Gosen, W., 2009. Stages of Late Palaeozoic deformation and intrusive activity in the western part of the North Patagonian Massif (southern Argentina) and their geotectonic implications. Geol. Mag. 146, 48-71.

von Gosen, W., Loske, W., 2004. Tectonic history of the Calcatapul Formation, Chubut province, Argentina, and the "Gastre fault system". J. South Am. Earth Sci. 18, 73-88.

Wang, K., Bilek, S.L., 2014. Invited review paper: fault creep caused by subduction of rough seafloor relief. Tectonophysics 610, 1-24.

Wells, R.E., Blakely, R.J., Sugiyama, Y., Scholl, D.W., Dinterman, P.A., 2003. Basincentered asperities in great subduction zone earthquakes: A link between slip, subsidence, and subduction erosion? J. Geophys. Res. Solid Earth 108, 2507-2536.

Wickert, A.D., 2016. Open-source modular solutions for flexural isostasy: gFlex v1.0. Geosci. Model. Dev. 9, 997-1017. https://doi.org/10.5194/gmd-9-997-2016.

Willner, A., Glodny, J., Gerya, T., Godoy, E., Massonne, H.-J., 2004. A counterclockwise PTt path of high-pressure/low-temperature rocks from the Coastal Cordillera accretionary complex of south-central Chile: constraints for the earliest stage of subduction mass flow. Lithos 75, 283-310.

Wright, N.M., Seton, M., Williams, S.E., Müller, R.D., 2016. The Late Cretaceous to recent tectonic history of the Pacific Ocean basin. Earth. Rev. 154, 138-173.

Zamora-Valcarce, G., Zapata, T., del Pino, D., Ansa, A., 2006. Structural evolution and magmatic characteristics of the Agrio fold-and-thrust belt. In: Kay, S.M., Ramos, V.A. (Eds.), Evolution of an Andean Margin: A Tectonic and Magmatic View from the Andes to the Neuquén Basin ( $35^{\circ}-39^{\circ} \mathrm{S}$ Lat), 407. Geological Society of America Special Paper, pp. 125-145. 